\title{
Leachate analyses of volcanic ashes from Stromboli volcano: A proxy for the volcanic gas plume composition?
}

\author{
E. Bagnato, ${ }^{1}$ A. Aiuppa, ${ }^{1,2}$ D. Andronico, ${ }^{3}$ A. Cristaldi, ${ }^{3}$ M. Liotta, ${ }^{2}$ L. Brusca, ${ }^{2}$ \\ and L. Miraglia ${ }^{3}$ \\ Received 17 December 2010; revised 27 May 2011; accepted 6 June 2011; published 14 September 2011.
}

[1] Many volcanoes show a change in chemical composition of the gas phase prior to periods of eruptive activity. Fine-grained tephra erupted from active vents and transported through volcanic plumes can adsorb, and therefore rapidly scavenge, volatile elements such as sulfur, halogens, and metal species in the form of soluble salts adhering to ash surfaces. Analysis of such water-soluble surface materials is a suitable supplement for remote monitoring of volcanic gases at inaccessible volcanoes. In this work, ash samples of the 2004 to 2009 eruptive activity of Stromboli volcano were sampled, leached, and analyzed for major and trace elements. Data analysis and interpretation was focused on determining the relationship between chemical composition of water-soluble components adhering to volcanic ash and the volcano's activity state. First results show significant temporal variations in ash leachate compositions, reflecting changes in the eruptive style of the volcano. In particular, we reveal that ash leachates $\mathrm{S} / \mathrm{F}$ and $\mathrm{Mg} / \mathrm{Na}$ ratios showed marked increases prior to a large-scale explosion on 15 March 2007.

Citation: Bagnato, E., A. Aiuppa, D. Andronico, A. Cristaldi, M. Liotta, L. Brusca, and L. Miraglia (2011), Leachate analyses of volcanic ashes from Stromboli volcano: A proxy for the volcanic gas plume composition?, J. Geophys. Res., 116, D17204, doi:10.1029/2010JD015512.

\section{Introduction}

[2] The complete characterization of volcanic ash is a suitable complement for monitoring the chemical composition of volcanic gases discharged from active volcanoes, particularly of poorly accessible ones. As volcanic gases leave the vent upon surface discharge/eruption, they mix with air and become oxidized. In response to these changes, condensation reactions occur, with fine-grained tephra often serving as catalysts for the formation of water-soluble minerals on their surfaces [Varekamp et al., 1984, 1986; Oskarsson, 1980]. These soluble materials, formed on the surface of volcanic ash, have been studied through water-leaching experiments for a long time [Lacroix, 1907; Taylor and Stoiber, 1973; Rose et al., 1973, 1978, 1980; Varekamp et al., 1984; Armienta et al., 2002; Edmonds et al., 2003; Mather et al., 2004; de Moor et al., 2005; Witham et al., 2005; Stewart et al., 2006; Delmelle et al., 2007]. The composition of these "ash leachates are thought to reflect, to some extent, the composition of some species in the volcanic plume [Delmelle et al., 2005; Horrocks et al., 2003; Stevenson et al., 2003; Edmonds et al., 2003; Mather et al., 2004]. Previous research demonstrated that up to $30 \%$ of the volatiles emitted during an

\footnotetext{
${ }^{1}$ Dipartimento CFTA, Università degli Studi di Palermo, Palermo, Italy. ${ }^{2}$ Istituto Nazionale di Geofisica e Vulcanologia, Sezione di Palermo, Palermo, Italy.

${ }^{3}$ Istituto Nazionale di Geofisica e Vulcanologia, Sezione di Catania, Catania, Italy.

Copyright 2011 by the American Geophysical Union. 0148-0227/11/2010JD015512
}

explosive eruption may become scavenged by adsorption processes on ash surface within the eruption column [Connor et al., 1993; Varekamp et al., 1984; de Hoog et al., 2001; Textor et al., 2003] (Figures 1a and 1b). Therefore, the analysis of pristine ash leachates provides important information on the eruption processes [Taylor and Stoiber, 1973; Oskarsson, 1980; Edmonds et al., 2003], and is often used to estimate the composition of the gas phase during volcanic eruptions [Taylor and Stoiber, 1973; Ossaka and Ozawa, 1975; Rose, 1977; Ossaka et al., 1998]. Ash leachate data may also provide useful information on the magmatic or phreatic character of an eruption [Armienta et al., 1998] and provide a good way to distinguish different eruptive styles within a single eruption (e.g., in 1980 at Mount St Helens' eruption [Stoiber and Williams, 1990]).

[3] Ash leachate data are presently unavailable for Stromboli volcano, notwithstanding this being one of the most studied volcanoes on Earth. Stromboli is the emergent portion of a $\sim 3.4 \mathrm{~km}$ high stratovolcano rising up to $924 \mathrm{~m}$ above sea level (Figures $2 \mathrm{a}$ and $2 \mathrm{~b}$ ) from the Tyrrhenian Sea, in the northernmost sector of the Aeolian Arc (South Italy). The volcano is famous for its eruptive style, that has become the archetype of "Strombolian activity": intermittent, mild explosions (Figure 3a) of incandescent lava fragments (bombs and lapilli) ejected up to 100-200 $\mathrm{m}$ height above the crater terrace (located at about $750-800 \mathrm{~m}$ above sea level), occurring on average every 5-20 min [Barberi et al., 1993, Rosi et al., 2000; Ripepe et al., 2005; Patrick et al., 2007; Andronico et al., 2008; Andronico, 2009; Andronico and Pistolesi, 2010]. The volcanic plume associated with 

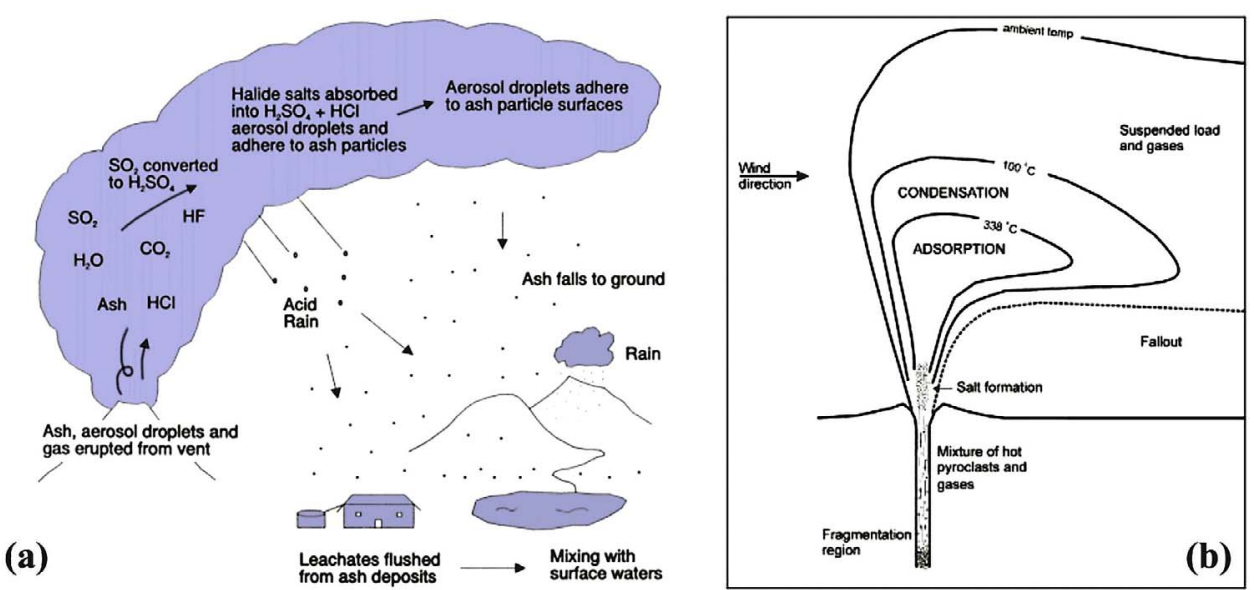

Figure 1. (a) A schematic diagram to show how volcanic gases (like $\mathrm{HCl}$ and $\mathrm{SO}_{2}$ ) reach the atmosphere and are scavenged by wet and dry deposition. (b) Three temperature-dependent zones within an eruption column [after Oskarsson, 1980].

this ordinary Strombolian explosive activity consists of a dispersion of gases $\left(\mathrm{H}_{2} \mathrm{O}, \mathrm{CO}_{2}, \mathrm{SO}_{2}\right.$, and $\mathrm{HCl}$ in roughly 1:0.2:0.02:0.02 proportions; [Allard et al., 1994, 2008; Burton et al., 2007; Aiuppa et al., 2010a, 2010b]) and metal-rich volcanic aerosols [Allard et al., 2000]. The ordinary explosions are sustained by a crystal-rich and degassed highly porphyritic (HP) magma, which resides within the upper part of the plumbing system [Bertagnini et al., 1999; Métrich et al., 2001]. The typical products associated with this activity are dark, relatively low-vesicularity scoriae rich in millimeter-size crystals, which commonly fall back onto the crater terrace. Scoriae contain $\sim 50$ vol. $\%$ crystals (Plag $\sim 65$; Cpx 25; Ol 10) [Métrich et al., 2001]. During periods of powerful ordinary explosive activity, however, ash and fine lapilli frequently reach the entire volcano's summit area (Pizzo sopra la Fossa and surroundings; Figure 2a); while in case of favorable winds, the erupted ash can travel as far as villages at the foot of the volcano.
[4] The explosive activity of Stromboli is also characterized by occasional, more violent than ordinary, explosive events. Based on their intensity, they have been named major explosions and paroxysms by some authors [Barberi et al., 1993; Bonaccorso et al., 1996; Bertagnini et al., 1999; Coltelli et al., 1999; Francalanci et al., 1999; Métrich et al., 2001] or more broadly paroxysms [Bertagnini et al., 1999], possibly ranging in size from small to large scale [Andronico and Pistolesi, 2010; Métrich et al., 2005; Métrich et al., 2010 ] by others. Figure $3 \mathrm{~b}$ shows an image captured during a paroxysmal explosion. These explosive events usually eject pumices (containing $<10$ vol. \% crystals with Plag $\sim 42-50$; Cpx $\sim 47-30$; Ol $\sim 11-20$ ) and are thought to be related to the fast ascent of volatile-rich magmas (the so-called LP magmas [Bertagnini et al., 2003; Métrich et al., 2005, 2010]) or gas slugs [Allard, 2010] bypassing the shallow volcano reservoir. To complete the common eruption scenarios occurring at Stromboli, the volcano also generates

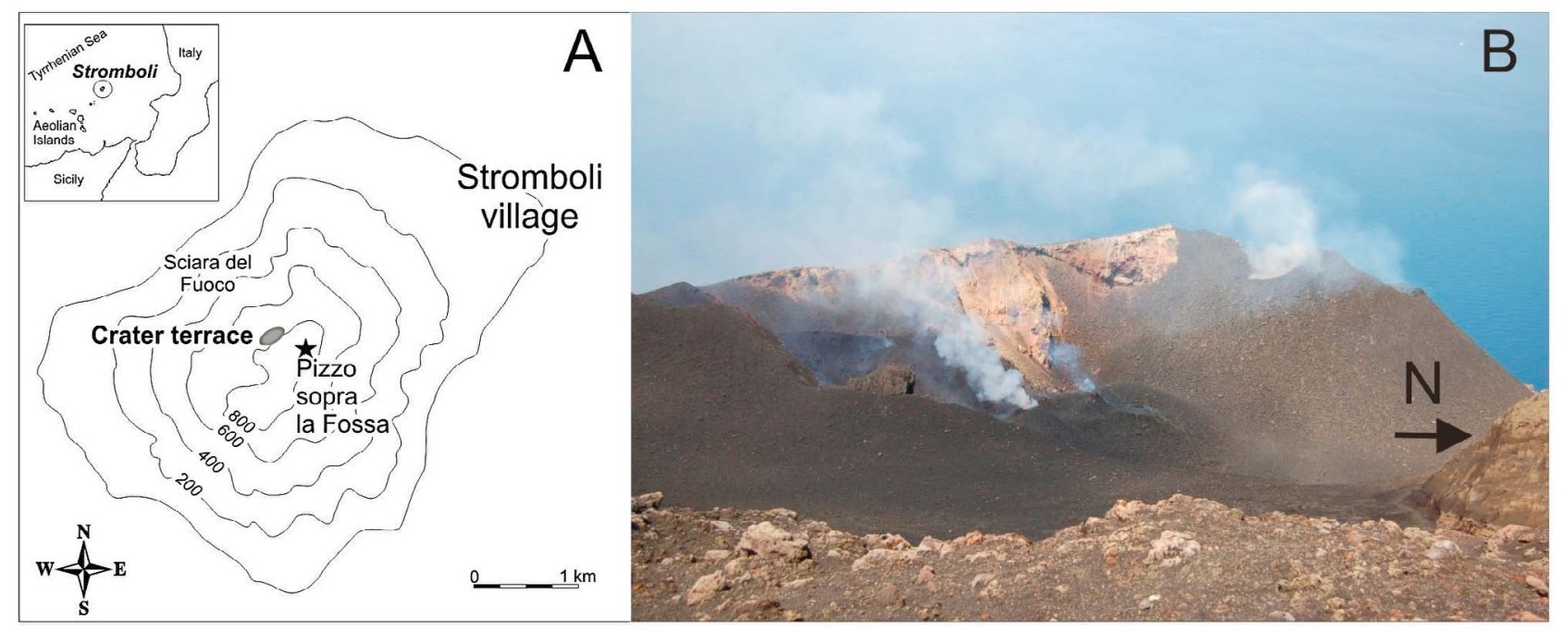

Figure 2. (a) Map of Stromboli $\left(38^{\circ} 47^{\prime} 38^{\prime \prime} \mathrm{N}, 15^{\circ} 12^{\prime} 40^{\prime \prime} \mathrm{E}\right)$. (b) Recent view of the crater terrace (image captured in May 2009 by D. Andronico). 


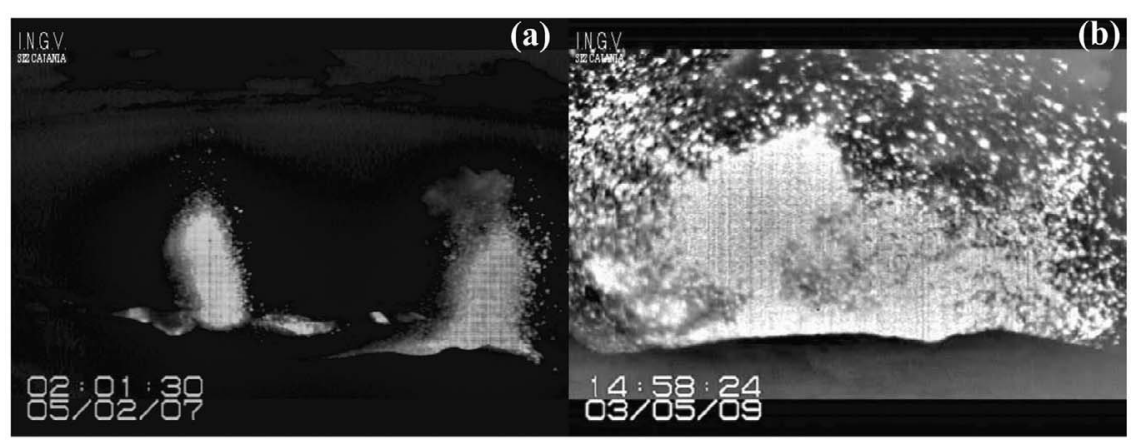

Figure 3. Infrared images captured by the monitoring camera managed by INGV-CT and located at Pizzo sopra La Fossa. (a) Examples of ordinary Strombolian explosions from the $\mathrm{N}$ and $\mathrm{S}$ areas of the crater terrace (on the right and left of the picture, respectively). (b) Major explosion/small-scale paroxysm on 3 May 2009. Note the involvement of the whole crater terrace by the products erupted during the paroxysmal explosion with respect to the ordinary explosions.

(typically once every ten years in the period 1888-1986 [Barberi et al., 1993]) effusive eruptions of HP magma from fissures typically opening on the upper flanks and supplying lava flows confined within the Sciara del Fuoco slope (Figure 2a) [Bertagnini et al., 2003]. Notably, during the last two effusive events in 2002-03 [e.g., Calvari et al., 2005] and 2007 [Barberi et al., 2009], two paroxysms shook the quiet lava effusion, on 5 April 2003 and 15 March 2007, respectively. The intense tephra fallout and ballistic shower from both paroxysms damaged a number of different scientific instruments in the summit area; in addition, up to multimetricsized bombs reached the villages of Ginostra (Figure 2a) causing severe damage to houses on 5 April [Pistolesi et al., 2008], and the lower flanks of the volcano up to about $300 \mathrm{~m}$ altitude on 15 March 2007 [Andronico et al., 2007; Barberi et al., 2009 and references therein]. Remarkably, during both paroxysms the absence of people on the upper flanks meant avoiding the loss of life.

[5] Because of its diverse and potentially hazardous eruptive activity recorded in the last years, today Stromboli has become a highly monitored volcano from a volcanological, geophysical, and geochemical point of view. In this context, the recurrent ashfallout between the summit area and the base of the volcano provides a unique opportunity to characterize the compositional features of ash leachates and to identify their relation (if any) with the eruptive activity styles.

[6] Here, we report the composition of leachates from volcanic ash samples collected during the 2004-2009 explosive activity of Stromboli. We first discuss in detail the compositional features of volatile species adsorbed on ash and compare our results with literature data from other volcanic systems. We then investigate the origin of adsorbed volatiles and attempt to address the question of whether or not the chemical composition of water-soluble components can be taken as a proxy of plume composition, and if it thus contains useful information for volcano monitoring purposes. To this end, we compare the compositional trends obtained by our analysis with the variations of the eruptive activity (mainly in terms of intensity and frequency of explosions and eruption style), including the period characterized by the 2007 lava flow eruption, and the following 15 March 2007 paroxysm. We conclude that the ash leachate $\mathrm{S} / \mathrm{F}$ and $\mathrm{Mg} / \mathrm{Na}$ ratios are the most sensitive parameters to probe degassing processes at Stromboli. Overall, our results suggest that ash leachates, if systematically monitored, may become powerful tools to detect (and potentially forecast) the arrival of S-rich basaltic magmas into the shallow plumbing system before a paroxysmal explosion.

\section{The 2004-2009 Eruptive Activity of Stromboli}

[7] After the 2002-2003 effusive eruption [Calvari et al., 2005; Pistolesi et al., 2008], Stromboli gradually resumed its ordinary Strombolian activity. In Figure 4, we report the Frequency of Explosions per day (avFE) [Andronico et al., 2008], calculated on the basis of the average number of explosions per hour from all the eruptive vents (see weekly reports published at Istituto Nazionale di Geofisica e Vulcanologia, Sezione di Catania (INGV-CT) website: www.ct.ingv.it).

[8] The diagram allows evaluating the temporal fluctuations in volcanic activity recorded over 6 years at Stromboli. Figure 4, in particular, shows periods (lasting up to a few weeks) characterized by high explosion frequency, alternated with "less active" intervals with relatively lower frequency of explosions. A few more explosive events (e.g., the 9 January 2005 "intermediate" explosion [Andronico et al., 2008]) were superimposed on this ordinary activity during 2004-2006, as typical of the volcano's behavior. By the end of January 2007, however, the explosion frequency significantly increased, ultimately leading (on 27 February) to the opening of an eruptive fissure on the upper slope of the Sciara del Fuoco, and thus the onset of the 2007 effusive eruption [Barberi et al., 2009]. During the effusive phase, no ordinary Strombolian activity was visible at the summit craters; the persistent occurrence of very-long-period seismicity [Giudicepietro et al., 2009] and of discontinuous (weak) ash emissions, however, were all suggestive that Strombolian activity persisted deep in the volcano's conduit [Marchetti and Ripepe, 2005]. This relatively quiet scenario was suddenly (and only very temporarily) interrupted by a paroxysmal explosion on 15 March 2007 [Aiuppa et al., 2010a, 2010b]; from a volcanological point of view, and for the purposes of this paper, this event may be viewed as one of the most powerful in the last 110 years, after the 1930 [Rittmann, 1931] and the 


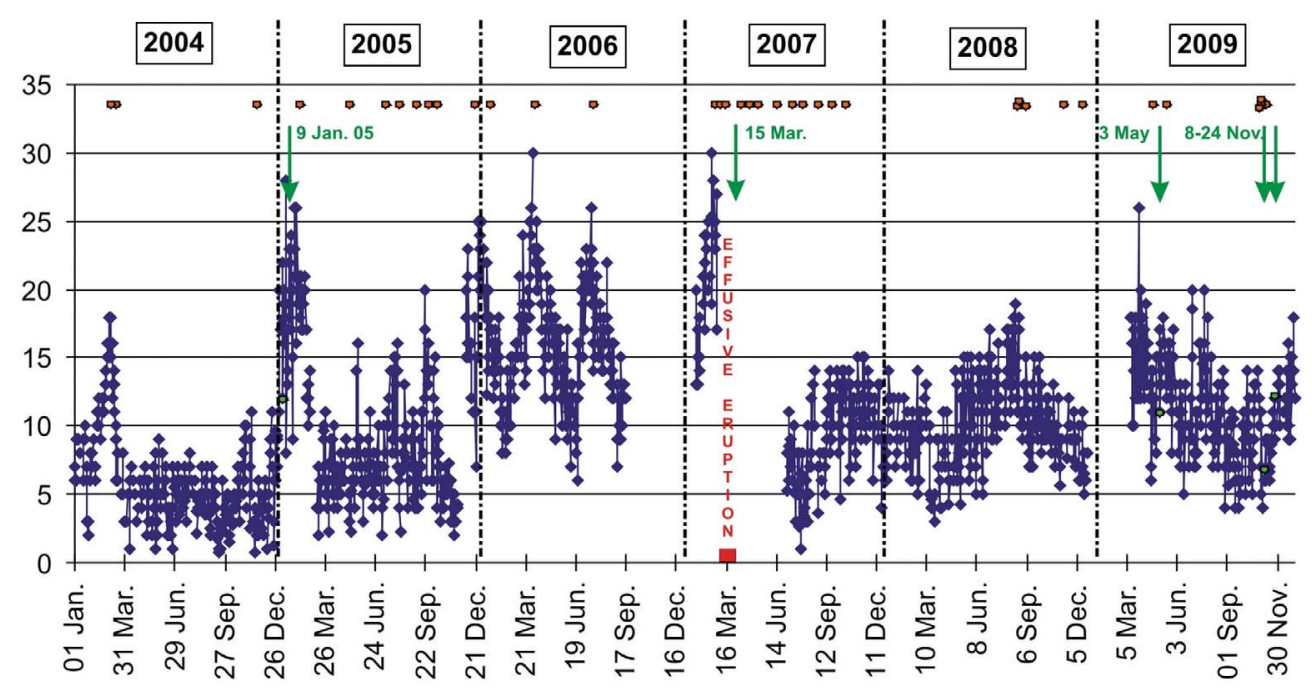

Figure 4. The total Frequency of Explosions per day (avFE) based on the average number of explosions per hour at Stromboli from 2004 to 2009. Green vertical arrows indicate the main eruptive events mentioned in section 6.2. Single or groups of samples here studied are labeled at the top of the plot (orange, full-colored circles). The red block on the bottom indicates the 2007 effusive eruption. Blank spaces indicate no images or insufficient data.

5 April 2003 [Calvari et al., 2005; Pistolesi et al., 2008] paroxysms [Métrich et al., 2010]. It could have temporarily modified/influenced the magma feeding system of Stromboli both before and after its occurrence. Whereas the effusive eruption finally came to an end on 2 April 2007, discontinuous ash-dominated explosions persisted for a few months, and it was only by the end of June 2007 that the ordinary Strombolian activity finally resumed. In 2008, Stromboli produced at least four major explosive events, with fairly similar features to those observed between 2004 and 2006. Finally in 2009, Stromboli produced again its indisputably (volcanologically speaking) typical major/ small-scale paroxysmal explosions (on 3 May and 8 and 24 November). These events were characterized by ballistic decimeter- to meter-sized spatter fallout in the upper slopes of the volcano, and light showers of centimeter-grained lapilli up to the coast and beyond.

\section{Methodology}

\subsection{Ash Samples Collection}

[9] Forty-three ash samples have been investigated for leachate analysis of major and trace elements (Table 1). Samples used in this work were selected among those collected at Stromboli from 2004 to 2009 during a high number of field surveys carried out by INGV-CT. Whereas our collection strategy was designed to uniformly cover the investigated time period with the best possible detail, the most significant ash samples come just from the period of activity encompassing the 2007 effusive eruption, and the 15 March large-scale paroxysm.

[10] Accurate criteria were followed for selecting the samples: These were unexposed to rain prior to collection (thus preventing possible "natural" leaching of the ash particles) and, when possible, collected during real-time observation of ordinary explosions or sporadic ash emissions on the volcano's summit. We therefore consider the selected samples representative of fresh-fallen ash, and overall uncontaminated/ unaltered by postdeposition processes. Most of the samples were collected in the summit area of Stromboli, between Pizzo sopra la Fossa $(918 \mathrm{~m})$ and the northern upper volcanic slopes down to $800 \mathrm{~m}$. Only a limited number of samples were recovered in other sites, located between the lower volcanic slopes and the inhabited areas of Stromboli (Table 1).

\subsection{Ash Leachates Analysis}

[11] Ash leaching was performed according to the method proposed by Armienta et al. [1998], and also suggested as a standard method by Witham et al. [2005]. For the leachate analysis, $1 \mathrm{~g}$ of ash was eluted with $25 \mathrm{ml}$ of $\alpha \mathrm{Q}$ grade Millipore water for $2 \mathrm{~h}$ with constant agitation. The solution was subsequently centrifuged at $3,500 \mathrm{rpm}$ for $15 \mathrm{~min}$ and filtered through $0.45 \mu \mathrm{m}$ Millipore filters, to remove fine suspended materials. The obtained solutions were then analyzed for $\mathrm{F}, \mathrm{Cl}, \mathrm{SO}_{4}, \mathrm{Na}, \mathrm{K}, \mathrm{Mg}$, and $\mathrm{Ca}$ contents by ion chromatography. Detection limits were between $0.005(\mathrm{~F})$ and $0.02\left(\mathrm{SO}_{4}\right) \mathrm{mg} / \mathrm{l}$ for anions and between 0.01 and $0.05 \mathrm{mg} / \mathrm{l}$ for cations. Trace elements ( $\mathrm{Li}, \mathrm{B}, \mathrm{V}, \mathrm{Cr}, \mathrm{Fe}, \mathrm{Ni}, \mathrm{Cu}, \mathrm{As}, \mathrm{Se}, \mathrm{Rb}$, $\mathrm{Sr}$, Mo, Sb, Cs, Th, U, Pb, Zn, Mn, Ti, Ba, Al, Cu, Co, Cd) in ash leachates solutions were also determined by inductively coupled plasma mass spectrometry (ICP-MS). Accuracy and precision of ICP-MS measurement were computed by analyzing certified reference materials (SLRS4, SPS-SW1, and SRM1643e) and by performing five replicates on samples; the relative errors are less than $10 \%$ for all the analyzed elements. The analyses performed by high-performance liquid chromatography were checked using certified reference material (NWCALGARY-93 from Calgary, Alberta, Canada) and was repeatedly analyzed during the each work session. Samples were analyzed in three different dilution factors. 
Table 1. List of the Ash Samples Used in This Study, Showing (When Available) the Provenance Vent Area Within the Crater Terrace (N, S, All Sectors), and the Location of Sampling Site (See Figure 2) ${ }^{\mathrm{a}}$

\begin{tabular}{|c|c|c|c|c|c|c|}
\hline $\begin{array}{l}\text { Sample } \\
\text { Number }\end{array}$ & Date & Sampling Location & $\begin{array}{c}\text { Crater } \\
\text { Area }\end{array}$ & $\begin{array}{l}\text { Main Mode(s) } \\
(\mathrm{mm})\end{array}$ & $\begin{array}{c}\text { Total Juvenile } \\
\text { (Sider. + Tach.) }\end{array}$ & Lithics + Crystals \\
\hline STR03 & 12 Mar 2004 & Pizzo & $\mathrm{N}$ & $0.1-0.25$ & $>60 \%$ & (G) \\
\hline STR02 & 19 Mar 2004 & Pizzo & & $0.5-1$ & $>60 \%$ & \\
\hline STR01 & 21 Nov 2004 & Pizzo & $\mathrm{N}$ & $0.2-0.5$ & & $>60 \%(\mathrm{G})$ \\
\hline STR06 & 08 Feb 2005 & $750 \mathrm{~m}$ - N flank & $\mathrm{N}$ & $2-3$ & $>60 \%$ & \\
\hline STR05 & 12 May 2005 & $750 \mathrm{~m}$ - N flank & $\mathrm{N}$ & $0.5-1$ & $>60 \%$ & $(\mathrm{G}+\mathrm{g})$ \\
\hline STR15 & 14 Jul 2005 & $750 \mathrm{~m}$ - N flank & $\mathrm{N}$ & $0.25-0.5$ & & $>60 \%(\mathrm{G})$ \\
\hline STR07 & 06 Aug 2005 & $750 \mathrm{~m}$ - N flank & $\mathrm{N}$ & $0,25-0.5$ & $\sim 50 \%$ & $\sim 50 \%(\mathrm{G})$ \\
\hline STR08 & 09 Sep 2005 & $750 \mathrm{~m}$ - N flank & $\mathrm{N}$ & $0.25-0.5$ & & $>60 \%$ \\
\hline STR14 & 23 Sep 2005 & $750 \mathrm{~m}$ - N flank & $\mathrm{N}$ & $0.5-1$ & $>60 \%$ & \\
\hline STR16 & 10 Oct 2005 & $750 \mathrm{~m}$ - N flank & $\mathrm{N}$ & $0.5-1$ & $>60 \%$ & (G) \\
\hline STR04 & 24 Dec 2005 & $750 \mathrm{~m}$ - N flank & $\mathrm{N}$ & $0.5-1$ & & $\sim 60 \%$ \\
\hline STR10 & 12 Jan 2006 & $750 \mathrm{~m}$ - N flank & $\mathrm{N}$ & $0.25-0.5$ & $>60 \%$ & \\
\hline STR11 & 12 Jan 2006 & $750 \mathrm{~m}$ - N flank & $\mathrm{N}$ & $0.5-1$ & $>60 \%$ & \\
\hline STR12 & 05 Apr 2006 & $750 \mathrm{~m}$ - N flank & $\mathrm{N}$ & $0.25-0.5$ & $>60 \%$ & \\
\hline STR13 & 05 Apr 2006 & $750 \mathrm{~m}$ - N flank & $\mathrm{N}$ & $1-2$ & $>60 \%$ & \\
\hline STR09 & 16 Jul 2006 & Pizzo & & $3-5$ & $>60 \%$ & \\
\hline STR28 & 02 Mar 2007 & $400 \mathrm{~m}$ - N flank & & $0.25-0.5$ & & $>60 \%(\mathrm{G})$ \\
\hline STR31 & 05 Mar 2007 & $\mathrm{COA}-80 \mathrm{~m}$ & $\mathrm{~N}$ & $0.1-0.25$ & & $>60 \%(\mathrm{G})$ \\
\hline STR29 & 15 Mar 2007 & Ginostra village & all sectors & $0.5-1$ & & $>60 \%(\mathrm{G})$ \\
\hline STR30 & 11 Apr 2007 & Ginostra village & & $0.25-0.5$ & & $>60 \%(\mathrm{G})$ \\
\hline STR32 & 19 Apr 2007 & Pizzo & & $0.1-0.25$ & & $>60 \%(\mathrm{G})$ \\
\hline STR33 & 25 Apr 2007 & $800 \mathrm{~m}, \mathrm{~N}$ flank & & $0.25-0.5$ & & $>60 \%(\mathrm{G}+\mathrm{g})$ \\
\hline STR23 & 23 Jun 2007 & Stromboli village & & $0.25-0.5$ & & $>60 \%(\mathrm{G})$ \\
\hline STR25 & 26 Jul 2007 & Pizzo & $\mathrm{S}$ & $0.1-0.25$ & & $>60 \%(\mathrm{G})$ \\
\hline STR22 & 03 Aug 2007 & Pizzo & $\mathrm{N}$ & $0.5-1$ & & $>60 \%(\mathrm{G}+\mathrm{g})$ \\
\hline STR26 & 20 Aug 2007 & Stromboli village & & $0.25-0.5$ & & $>60 \%(\mathrm{G}+\mathrm{g})$ \\
\hline STR21 & 02 Sep 2007 & Pizzo & $\mathrm{S}$ & $0.1-0.25$ & & $>60 \%(\mathrm{G})$ \\
\hline STR27 & 22Sep 2007 & Stromboli village & $\mathrm{S}$ & $0.25-0.5$ & $>60 \%$ & (g) \\
\hline STR24 & 22 Oct 2007 & Pizzo & $\mathrm{N}$ & $1-2$ & & $>60 \%(\mathrm{~g})$ \\
\hline STR17 & 01 Sep 2008 & Pizzo & $\mathrm{S}$ & $0.25-0.5$ & & $>60 \%(\mathrm{G})$ \\
\hline STR18 & 02 Sep 2008 & Pizzo & $\mathrm{S}$ & $0.5-1$ & $\sim 60 \%$ & \\
\hline STR19 & 02 Sep 2008 & Pizzo & $\mathrm{S}$ & $0.5-1$ & $\sim 60 \%$ & \\
\hline STR20 & 05 Sep 2008 & Pizzo & $\mathrm{S}$ & $0.5-1$ & & $\sim 60 \%$ \\
\hline STR34 & 17 Nov 2008 & Ginostra & & $0.25-0.5$ & & $\sim 60 \%(\mathrm{G})$ \\
\hline STR35 & 16 Dec 2008 & Pizzo & $\mathrm{N}$ & $0.25-0.5$ & $\sim 50 \%$ & $\sim 50 \%$ \\
\hline STR36 & 24 Apr 2009 & Pizzo & & $0.1-0.25$ & $>60 \%$ & \\
\hline STR37 & 03 May 2009 & Pizzo & $\mathrm{N}$ & $0.25-0.5$ & & $\sim 60 \%(\mathrm{G})$ \\
\hline STR38 & 10 May 2009 & Pizzo & $\mathrm{S}$ & $0.25-0.5$ & $\sim 50 \%$ & $\sim 50 \%$ \\
\hline STR39 & 29 Oct 2009 & Pizzo & $\mathrm{N}$ & $0.1-0.25$ & & $>60 \%$ \\
\hline STR40 & 29 Oct 2009 & Pizzo & $\mathrm{N}$ & $0.25-0.5$ & & $>60 \%$ \\
\hline STR41 & 29 Oct 2009 & Pizzo & $\mathrm{N}$ & $0.25-0.5$ & & $>60 \%$ \\
\hline STR42 & 29 Oct 2009 & Pizzo & $\mathrm{N}$ & $0.25-0.5$ & & $>60 \%$ \\
\hline STR43 & 18 Oct 2009 & Pizzo & & $0.25-0.5$ & & $>60 \%$ \\
\hline
\end{tabular}

${ }^{a}$ For each sample, the prevalent grain size modes and the dominant class of componentry are also reported. Samples marked by the symbol "G" and " $\mathrm{g}$ " (column: Lithics+Crystals) are those for which a significant fraction of gypsum crystals was observed: "G" stands for large ( $>0.1$ mm) skeletal/tabular single crystals (likely hydrothermally derived), while "g" stands for finer $(<0.1 \mathrm{~mm})$ interstitial crystals (usually occurring as aggregates), respectively.

The relative errors are less than $10 \%$ for all the analyzed elements. Analytical determinations were all performed at INGV, Sezione di Palermo.

\subsection{Errors and Uncertainties}

[12] In considering ash leachates as chemical proxies for the volcanic gas plume, understanding both analytical errors and the complexity of the plume chemical processes is crucial. Uncertainties in ash leachates analysis result from variations in the timing of ash/water interaction. As an example, since sulfate concentrations are quite sensitive to ash/water ratios, low interaction times may give misleadingly low concentrations if the sulfates do not attain complete dissolution. To reduce this error, tests of sequential extractions of the same sample in different time intervals (from a few hours to more than one day) have been performed to ensure complete dissolution of the soluble material adsorbed on ash surfaces. These tests confirmed that complete dissolution of soluble phases was completed after $2 \mathrm{~h}$. Further uncertainties may result from the higher solubility in water of chlorine relative to sulfate: Rain falling onto ash samples before collection may cause preferential leaching of chlorine from the ash surfaces, resulting in reduced $\mathrm{HCl} / \mathrm{SO}_{2}$ ratios in leachate solutions. This effect has been minimized by collecting ash samples unexposed to rain events.

\section{Generalities on Water-Soluble Components Adhering to Volcanic Ash}

[13] The analysis of water-soluble materials adhering to ash surfaces represents an alternative (though indirect) tool to obtain information on plume chemistry. The elements dissolved in aqueous extracts represent components of watersoluble materials either formed directly in the eruption cloud 
or derived from interaction of ash particles and plume aerosol components. In volcanic plumes, tiny particles form as a result of vapor condensation, reaction of vapor with air, or reaction of vapor or condensed liquids with silicate fragments [Oskarsson, 1980]. In detail, Oskarsson [1980] proposed a model to explain the presence of water-soluble materials formed by condensation/sublimation of volcanic gases onto ash surfaces, based on the existence of three distinct temperature-dependent reaction zones within an eruption cloud (Figure 1b). Each zone accounts for a specific type of reaction involving acidic magmatic gases (such as $\mathrm{SO}_{2}, \mathrm{HCl}$, and HF): (i) the salt formation zone, in the hot core of the eruption clouds, where sulfate and halite salt aerosols form at near magmatic temperatures; (ii) the surface adsorption zone, where halogen gases react with ash surfaces at lower temperature $\left(<700^{\circ} \mathrm{C}\right)$; (iii) and the condensation zone, which is characterized by the formation of sulfuric and halogen acids at temperatures below $338^{\circ} \mathrm{C}$. These compounds will also adsorb onto ash particles. Among these, the most common processes are gas-to-particle conversion of $\mathrm{SO}_{2}$ to sulfate $\left(\mathrm{SO}_{4}\right)$ and the formation of acid droplets from the condensation of $\mathrm{HCl}$ from the vapor phase (Figure 1b). The origin of the major cations in the adsorbed material is less clear, but often ascribed to the dissolution of ash constituents by the corrosive action of halide and sulfate acids in the plume. This could supply the major alkali and alkaline-earth cations [Delmelle et al., 2007; Liotta et al., 2006]. Furthermore, secondary minerals may ultimately precipitate after cations dissolution inside a liquid film on ash particles [Delmelle et al., 2005; Rose et al., 1980; Casadevall et al., 1984]. Previous studies [Delmelle et al., 2007; Moune et al., 2006] documented that in-plume ash dissolution is most efficient near the volcanic vents, during the first minutes of transport of the eruption cloud, and depends on many factors such as the initial composition of the vapor phase, the time spent by ash particles in the volcanic plume, and the surface area of ash.

\section{Results}

\subsection{Composition, Morphology, and Grain Size of Ash Samples at Stromboli}

[14] Ash samples collected at Stromboli are mixtures of four main types of particles: sideromelane, tachylite, lithics, and crystals. Sideromelane is mostly transparent to light yellow to brown with smooth surfaces and variable vesicularity; it can be found with different shapes, ranging from irregularly fluidal to elongated (forming short filaments of glass similarly to small-scale Pele's hair) to partially angular glass fragments. Tachylites are usually shiny black, blocky, nonvesicular glassy particles. These two components represent the juvenile materials directly related to the magma within the volcanic conduits; sideromelane is considered to form by the ejection of droplets of hot magma that plastically deform during flight in the air, whereas tachylites represent fragments of partially cooled more crystalline magma. Conversely, lithics are subrounded to angular particles, consisting of older and/or altered juvenile particles or fragments of preexisting rocks; hence, they are erupted already solidified. Finally, crystals are usually represented by plagioclase, pyroxene, olivine, and secondary particles, mainly gypsum.

[15] These components were present in variable percentage within each ash sample (Table 1) depending on intensity of the explosions and,above all, the depth of the magma surface. Generally, ash samples composed of totally sideromelane particles are indicative at Stromboli of a high magma level in the volcanic conduits and efficient fragmentation process; samples in which lithic particles are predominant reflect a high percentage of recycled ash from the conduits and the craters walls, or deep (less efficient) magma fragmentation. It is thus not surprising to observe that samples collected during the 2007 effusive unrest, when the magma was not visible at the upper vents, and Strombolian activity confined deep in the conduits were dominated by partially recycled and not very fresh ash silicate fragments (tentatively classified as lithic fragments in Table 1). This contrasts with samples from the 2004-2006 period, when ordinary Strombolian activity was generally sourced by magma ponding on the crater's terrace and in which juvenile (sideromelane, tachylite) fragments prevailed. The 2008-2009 phase showed intermediate componentry between 2007 and 2004-2006, consistent with gradual resumption of ordinary Strombolian activity after the effusive eruption. Both fine-grained $(<0.1 \mathrm{~mm})$ interstitial ( $\mathrm{g}$ in Table 1$)$ and larger $(>0.1 \mathrm{~mm})$ skeletal ( $\mathrm{G}$ in Table 1$)$ gypsum crystals were commonly present, and were particularly abundant in sample STR05 and STR26.

[16] As for their textures, Stromboli's ash fragments range in size from $<0.1 \mathrm{~mm}$ to $>2 \mathrm{~mm}$, but have grain size distributions with modes typically in the $0.25-0.5$ to $0.5-1 \mathrm{~mm}$ classes (Table 1). We observe, however, that during the 2007 effusive unrest, when the ordinary explosions Strombolian at the summit vents had been replaced by weak discontinuous ash emissions, ash samples were typically characterized by a larger abundance of finer particles (with modes dominantly in the $0.1-0.25$ and $0.25-0.5$ classes) (Table 1 ).

\subsection{Chemical Composition of Ash Leachates: Major Elements}

[17] The abundances of water-soluble components on Stromboli ash fragments, listed in Table 1, show a large spread of compositions (Table 2). The most abundant elements in water leachates are sulfate (among anions) and calcium (among cations), with mean concentrations of 9,984 and $2,106 \mu \mathrm{g} / \mathrm{g}$, respectively (Table 2). Sulfate concentrations are a factor $\sim 5$ lower in 2004-2006 samples (mean value of $230 \mu \mathrm{g} / \mathrm{g})$ than in 2007-2009 $(\sim 15763 \mu \mathrm{g} / \mathrm{g})$. The mean chlorine content in Stromboli's ash leachates is in the order of $2,160 \mu \mathrm{g} / \mathrm{g}$, whereas fluorine has mean concentration of $1,405 \mu \mathrm{g} / \mathrm{g}$. These results concur well with previous studies by Delmelle et al. [2005, 2007], who pointed out that sulfur, as sulfate $\left(\mathrm{SO}_{4}^{2-}\right)$, chlorine $(\mathrm{Cl})$, and fluorine $(\mathrm{F})$ (ranked in decreasing order of abundance) are the most enriched elements on the ash surface compared to its bulk composition.

\subsection{The Origin of Major Elements in Ash Leachates}

[18] The scatterplot of Figure 5a reveals that ash leachates have sulfur to chlorine proportions falling within the range of bulk plume $\mathrm{S} / \mathrm{Cl}$ ratios (data from Allard et al. [2000]). This supports a prevalent volcanogenic origin of the two elements and confirms that adsorption of plume acidic gas species (e.g., $\mathrm{SO}_{2 \mathrm{~g}}$ and $\mathrm{HCl}_{\mathrm{g}}$ [Allard et al., 2000]) onto volcanic ash is among the key controlling factors on ash leachate chemistry, as also documented at other volcanoes [Taylor and Stoiber, 1973; Smith et al., 1982, 1983; Varekamp and Luhr, 1996]. 
Table 2. Major Soluble Species Concentrations on Ash, Derived From Ash Leachate Analysis for Samples Collected During 2004-2009 at Stromboli Volcano and the Mean Chemical Composition of Stromboli Volcanic Ash ${ }^{\mathrm{a}}$

\begin{tabular}{|c|c|c|c|c|c|c|c|c|c|c|}
\hline Sample & Date & $\mathrm{F}$ & $\mathrm{Cl}$ & $\mathrm{SO}_{4}$ & $\mathrm{Ca}$ & $\mathrm{K}$ & $\mathrm{Mg}$ & $\mathrm{Na}$ & $\begin{array}{c}\mathrm{SO}_{2} / \mathrm{HCl} \\
\text { Molar }\end{array}$ & $\begin{array}{r}\mathrm{SO}_{2} / \mathrm{HF} \\
\text { Molar }\end{array}$ \\
\hline STR01 & 02 Dec 2004 & 176.2 & 11.3 & 31.6 & 3.2 & 9.7 & 3.3 & 22.4 & 1.0 & 0.04 \\
\hline STR02 & 18 Mar 2004 & 169.3 & 201.2 & $1,229.1$ & 400.6 & 47.5 & 29.2 & 215.6 & 2.3 & 1.44 \\
\hline STR03 & 12 Mar 2004 & 62.5 & 157.9 & $1,347.5$ & 467.5 & 127.4 & 36.1 & 216.1 & 3.2 & 4.27 \\
\hline STR04 & 24 Dec 2005 & 36.4 & 4.3 & 22.3 & 3.9 & 9.1 & 1.7 & 19.0 & 1.9 & 0.12 \\
\hline STR05 & 12 May 2005 & 111.5 & 5.9 & 194.0 & 77.0 & 9.5 & 6.7 & 14.0 & 12.1 & 0.34 \\
\hline STR06 & 08 Feb 2005 & 83.3 & 29.5 & 38.7 & 5.7 & 6.4 & 2.9 & 16.6 & 0.5 & 0.09 \\
\hline STR07 & 06 Jun 2005 & 93.4 & 15.5 & 234.6 & 81.1 & 15.1 & 6.4 & 22.2 & 5.6 & 0.50 \\
\hline STR08 & 09 Sep 2005 & 34.4 & 9.7 & 21.5 & 4.9 & 8.0 & 2.3 & 14.4 & 0.8 & 0.12 \\
\hline STR14 & 23 Sep 2005 & 459.6 & 26.5 & 39.5 & 5.9 & 6.7 & 3.7 & 18.8 & 0.5 & 0.02 \\
\hline STR15 & $14 \mathrm{Jul} 2005$ & 78.2 & 0.9 & 10.5 & 5.1 & 4.1 & 1.4 & 6.3 & 4.5 & 0.03 \\
\hline STR16 & 10 Oct 2005 & 49.5 & 25.6 & 20.3 & 4.2 & 2.5 & 4.0 & 23.5 & 0.3 & 0.08 \\
\hline STR09 & 16 Jul 2006 & 31.8 & 122.8 & 454.9 & 175.3 & 26.5 & 17.7 & 75.3 & 1.4 & 2.83 \\
\hline STR10 & 12 Jan 2006 & 63.2 & 6.1 & 12.9 & 2.4 & 6.4 & 1.2 & 23.0 & 0.8 & 0.04 \\
\hline STR11 & $12 \operatorname{Jan} 2006$ & 51.9 & 4.3 & 7.0 & 0.1 & 3.8 & 0.3 & 20.2 & 0.6 & 0.03 \\
\hline STR12 & 05 Apr 2006 & 55.8 & 3.5 & 19.0 & 2.6 & 9.0 & 1.3 & 20.0 & 2.0 & 0.07 \\
\hline STR13 & 05 Apr 2006 & 51.8 & 5.2 & 9.4 & 0.9 & 6.0 & 1.0 & 18.0 & 0.7 & 0.04 \\
\hline STR21 & 02 Sep 2007 & $5,305.7$ & $16,446.3$ & $12,726.3$ & $6,428.5$ & $1,053.5$ & $3,690.1$ & $2,616.1$ & 0.3 & 0.47 \\
\hline STR22 & 03 Aug 2007 & $2,536.2$ & $1,249.9$ & $17,547.1$ & $1,928.9$ & $1,161.9$ & $1,863.3$ & $1,766.5$ & 5.2 & 1.37 \\
\hline STR23 & 23 Jun 2007 & $1,302.5$ & $2,562.0$ & $53,612.8$ & $3,220.1$ & $3,264.7$ & $4,895.5$ & $5,396.2$ & 7.7 & 8.15 \\
\hline STR24 & 22 Oct 2007 & 610.0 & 519.5 & $8,255.5$ & 829.7 & 459.9 & 612.9 & 682.5 & 5.9 & 2.68 \\
\hline STR25 & 26 Jul 2007 & 672.8 & $3,820.9$ & $35,469.5$ & $4,921.4$ & $1,732.6$ & $5,150.0$ & $4,786.6$ & 3.4 & 10.43 \\
\hline STR26 & 20 Aug 2007 & 524.6 & 301.6 & $11,408.6$ & $2,312.9$ & 946.2 & 647.4 & $1,162.5$ & 14.0 & 4.30 \\
\hline STR27 & 28 Sep 2007 & $1,448.6$ & $1,140.0$ & $7,034.0$ & $1,684.0$ & 260.4 & 815.9 & 666.0 & 2.3 & 0.96 \\
\hline STR28 & 02 Mar 2007 & $1,059.3$ & $10,619.0$ & $30,019.3$ & $8,962.0$ & 23.4 & $6,162.7$ & $4,428.0$ & 1.0 & 5.61 \\
\hline STR29 & 15 Mar 2007 & 103.4 & $3,870.0$ & $19,924.3$ & $4,995.8$ & 784.9 & $3,168.9$ & $3,158.6$ & 1.9 & 38.12 \\
\hline STR30 & 11 Apr 2007 & 211.7 & $5,270.0$ & $16,460.4$ & $6,571.2$ & 88.2 & $2,233.4$ & $1,620.8$ & 1.2 & 15.39 \\
\hline STR33 & 05 Mar 2007 & 381.7 & $11,891.0$ & $55,280.0$ & $11,234.6$ & $1,330.4$ & $8,727.8$ & $6,295.0$ & 1.7 & 28.66 \\
\hline STR36 & 25 Apr 2007 & $1,738.9$ & 431.4 & $9,095.2$ & $12,290.4$ & $2,483.9$ & $8,343.8$ & $5,412.7$ & 7.8 & 1.04 \\
\hline STR37 & 19 Apr 2007 & $8,733.8$ & $18,765.8$ & $24,478.2$ & $9,072.6$ & 28.1 & $4,845.6$ & $2,551.0$ & 0.5 & 0.55 \\
\hline STR17 & 01 Sep 2008 & $1,070.7$ & 151.0 & $2,354.6$ & 477.5 & 128.4 & 46.1 & 580.1 & 5.8 & 0.44 \\
\hline STR18 & 02 Sep 2008 & $1,124.2$ & 455.1 & $2,023.6$ & 483.4 & 96.0 & 59.9 & 523.6 & 1.6 & 0.36 \\
\hline STR19 & 03 Sep 2008 & 84.5 & 19.3 & 60.6 & 28.3 & 10.3 & 6.9 & 12.9 & 1.2 & 0.14 \\
\hline STR20 & 05 Sep 2008 & $1,394.7$ & 317.4 & $1,711.9$ & 374.7 & 80.2 & 54.9 & 542.9 & 2.0 & 0.24 \\
\hline STR31 & 17 Nov 2008 & 706.1 & 365.4 & $1,073.4$ & 489.7 & 57.6 & 32.1 & 387.9 & 1.1 & 0.30 \\
\hline STR38 & 16 Dec 2008 & 290.5 & 293.4 & $1,236.7$ & 288.2 & 46.4 & 27.0 & 340.5 & 1.6 & 0.84 \\
\hline STR32 & 03 May 2009 & $1,963.5$ & $7,377.7$ & $78,625.5$ & $1,864.5$ & 761.9 & 168.8 & $1,611.1$ & 3.9 & 9.19 \\
\hline STR34 & 10 May 2009 & 100.7 & 218.0 & $1,103.5$ & 452.4 & 6.0 & 2.2 & 18.9 & 1.9 & 2.17 \\
\hline STR35 & 24 Apr 2009 & $3,212.9$ & 739.6 & $1,819.4$ & $1,859.3$ & 345.7 & 124.9 & 738.4 & 0.9 & 0.11 \\
\hline STR39 & 29 Oct 2009 & $1,670.2$ & $1,023.0$ & $8,228.2$ & $2,179.6$ & 236.5 & 208.5 & 791.1 & 3.0 & 0.98 \\
\hline STR40 & 29 Oct 2009 & $1,726.6$ & $1,227.5$ & $8,556.4$ & $1,810.9$ & 323.9 & 283.9 & $1,127.8$ & 2.6 & 0.98 \\
\hline STR41 & 29 Oct 2009 & $1,118.1$ & 949.0 & $7,006.8$ & $1,498.5$ & 246.7 & 216.7 & 874.1 & 2.7 & 1.24 \\
\hline STR42 & 29 Oct 2009 & $1,509.8$ & 644.8 & $6,470.9$ & $1,385.5$ & 258.3 & 178.1 & 804.1 & 3.7 & 0.85 \\
\hline STR43 & 18 Nov 2009 & $18,492.1$ & $1,611.5$ & $4,036.6$ & $1,710.0$ & 354.2 & 164.3 & 567.5 & 0.9 & 0.04 \\
\hline Plume composition ${ }^{\mathrm{b}}$ & & 68 & 1,434 & 6,563 & 52 & 17 & 3 & 31 & & \\
\hline Ash composition ${ }^{\mathrm{b}, \mathrm{c}}$ & & 600 & 550 & 40 & 65,900 & 17,300 & 39,234 & 18,570 & & \\
\hline
\end{tabular}

${ }^{\mathrm{a}}$ Concentrations are in micrograms per gram of ash, except for the plume chemical composition, which is expressed as micrograms per cubic meter [Allard et al., 2000]. Besides, S/Cl and S/F molar ratios in ash leachates are also reported.

[19] If $\mathrm{F}$ concentrations are also taken into account, however, a more complex scenario emerges (Figure 6a). First, it is clear from the triangular diagram of Figure $6 a$ that ash leachates are in most cases far richer in $\mathrm{F}$ (relative to $\mathrm{S}$ and $\mathrm{Cl}$ ) than the bulk plume, which implies that-even accepting that the plume is the main source of the three volatiles-gas-ash interactions must be gas-specific (e.g., $\mathrm{HF}_{\mathrm{g}}$, the most abundant $\mathrm{F}$ species in Stromboli's plume, must be more effectively scavenged by ash than $\mathrm{SO}_{2 \mathrm{~g}}$ and $\mathrm{HCl}_{\mathrm{g}}$ ) [Oskarsson, 1980]. Selective $\mathrm{HF}_{\mathrm{g}}$ deposition onto ash can indeed explain the high $\mathrm{F}$ concentrations in ash leachate solutions, where $\mathrm{F}$ occasionally predominates over $\mathrm{Cl}$ and $\mathrm{S}$ concentrations (Table 2), in spite of being a relatively minor constituent of volcanic gas discharges in general [Symonds et al., 1994], and at Stromboli in particular [Allard et al.,
2008]. Second, it is clear from Figure 6a that S:Cl:F proportions in ash leachates are highly variable, implying that either (i) the plume varied substantially (during 2004-2009) around its time-averaged composition; (ii) plume composition remained fairly constant, but plume-ash reactions varied to some extent in their dynamics (and thus products); or (iii) other $\mathrm{S}, \mathrm{F}, \mathrm{Cl}$ sources (other than the plume alone) have to be considered. Among these, the remobilization of hydrothermal minerals from the volcano's conduit system, and their entrainment in the plume as lithic fragments, is possibly a recurrent process [Witham et al., 2005; Cronin et al., 2003].

[20] Figure 6b shows that there is also a large spread of cation species composition, likely indicative of the existence of a variety of sources. We observe that the 2007 ash leachate 

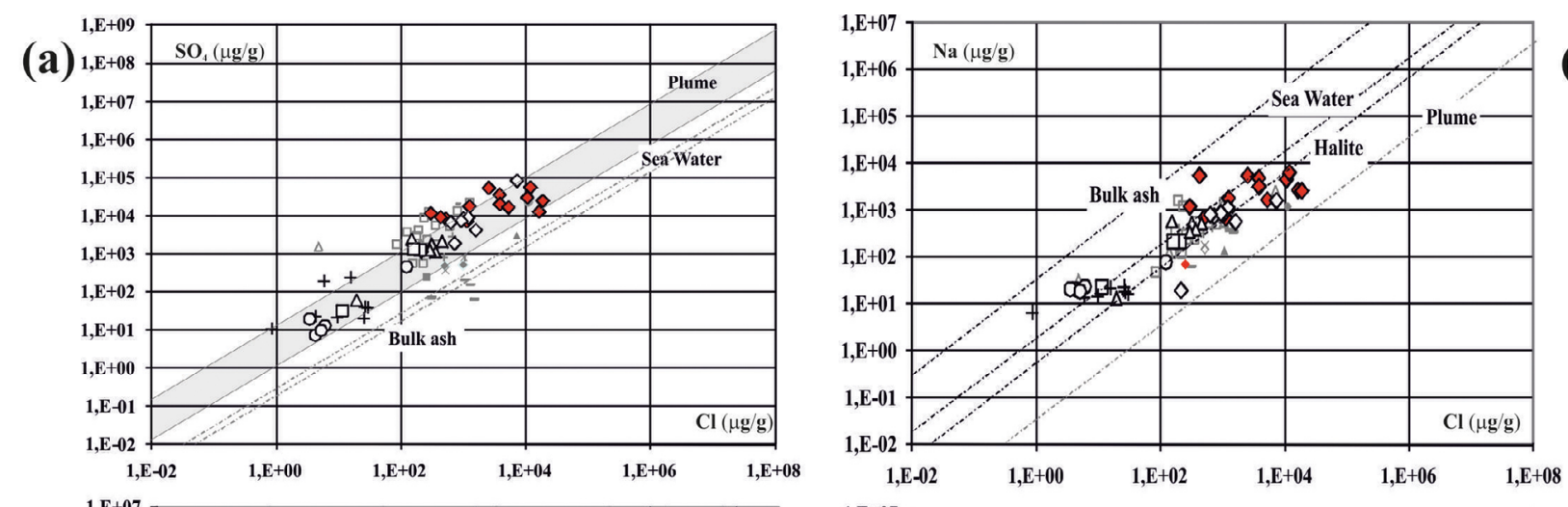

(b)

(c)
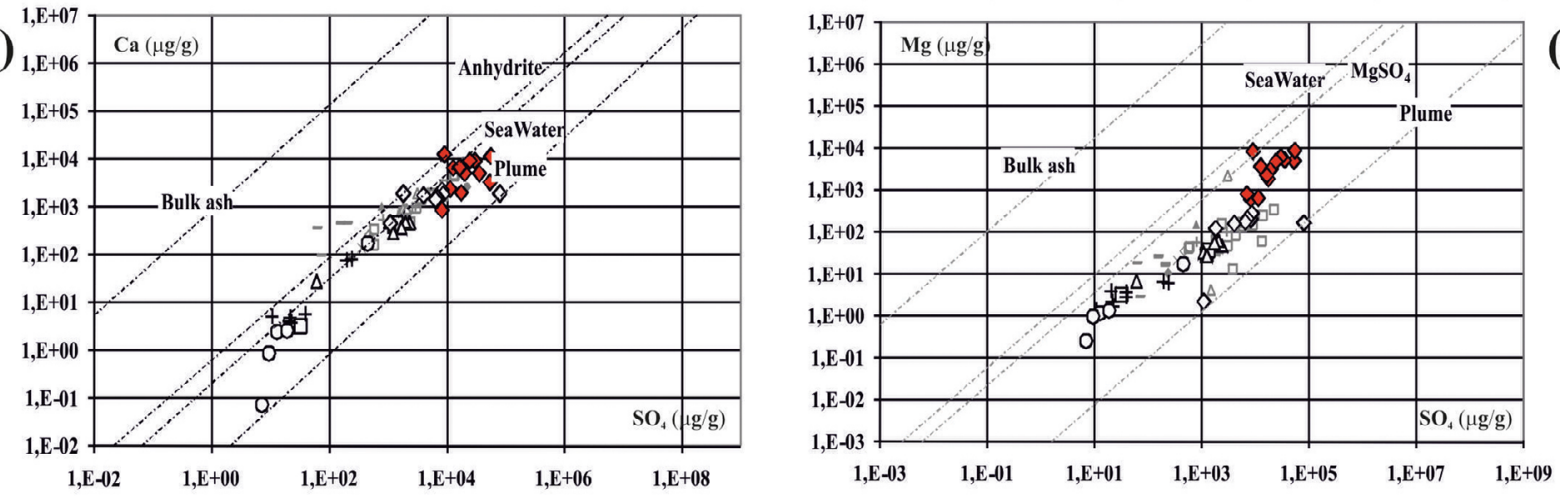

(d)

(e)
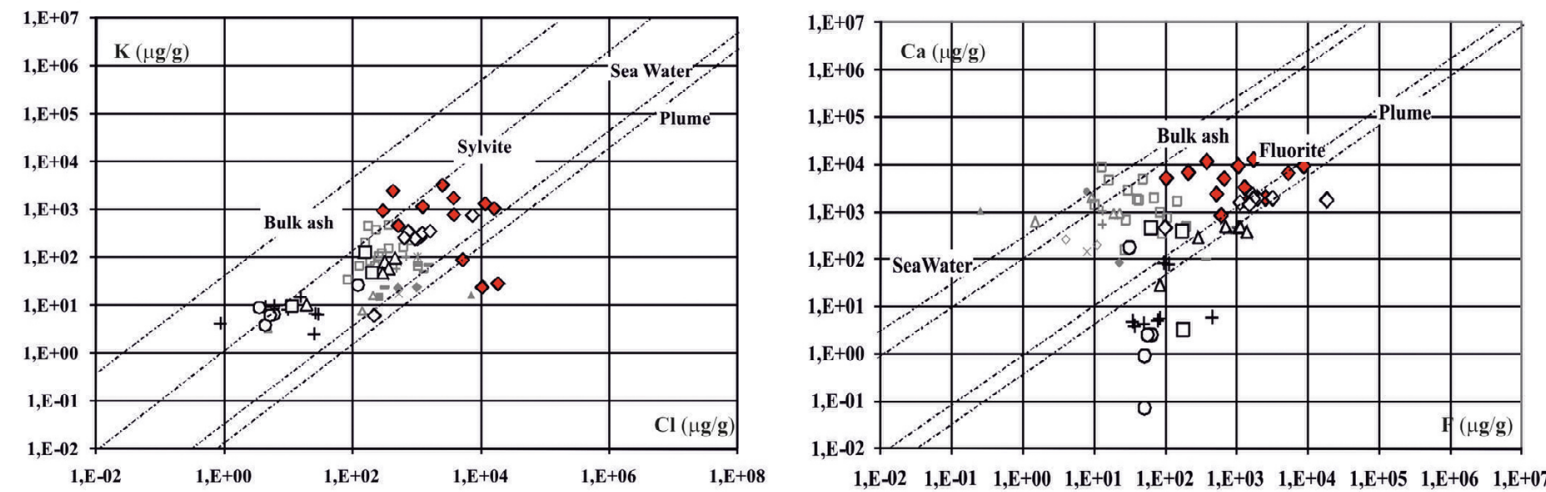

(f)

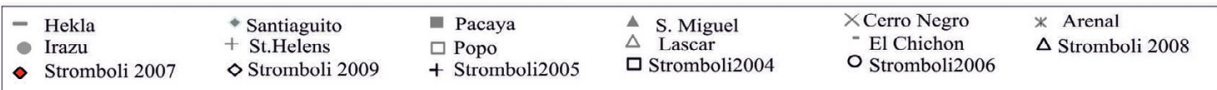

Figure 5. Scatterplots correlating the molar abundances of cation and anion species in ash leachates from Stromboli (this work; black and red samples): (a), $\mathrm{SO}_{4}$, (b) $\mathrm{Na}$, (c) $\mathrm{Ca}$, (d) $\mathrm{Mg}$, (e) $\mathrm{K}$, and (f) $\mathrm{Ca}$ (see sections 5.3 and 5.4 for details). The gray zone indicates the plume's chemical composition range for the reported species. Samples from 2007 Stromboli's eruption are reported in red. Data from other volcanoes (gray) are also reported. Data sources are Oskarsson [1980]; Taylor and Stoiber [1973]; Smith et al. [1983]; Cronin et al. [2003]; Christenson [2000]; Varekamp et al. [1984]; de Hoog et al. [2001]; Hinkley and Smith [1982]; Risacher and Alonso [2001]; and Armienta et al. [2002].

samples form a relatively narrow cluster, characterized by unusually $\mathrm{Mg}$-rich composition. These samples overlap the average composition of Stromboli's bulk ash [Allard et al., 2000], demonstrating that leaching of silicate (either juvenile or lithic) fragments by plume acidic species likely provided the majority of cations to water-soluble solid materials deposited on ash surface (and thus to leachates). More in detail, olivine is very soluble in sulfuric acid, and the presence of olivine crystals that are covered in sulfuric acid may play a role in this as well. In fact, scoriae at Stromboli contain about $50 \%$ crystals constituted by Plag $\sim 65$; $\mathrm{Cpx} \sim 25$; Ol $\sim 10$, this last exhibiting a narrow compositional range Fo70-75 [Métrich et al., 2001]. This mineral assemblage may suggest that olivine dissolution is the main source of $\mathrm{Mg}$ to leachates.

[21] The remaining (2004-2009) samples have distinct cation compositions to that of the ash they were leached from: 


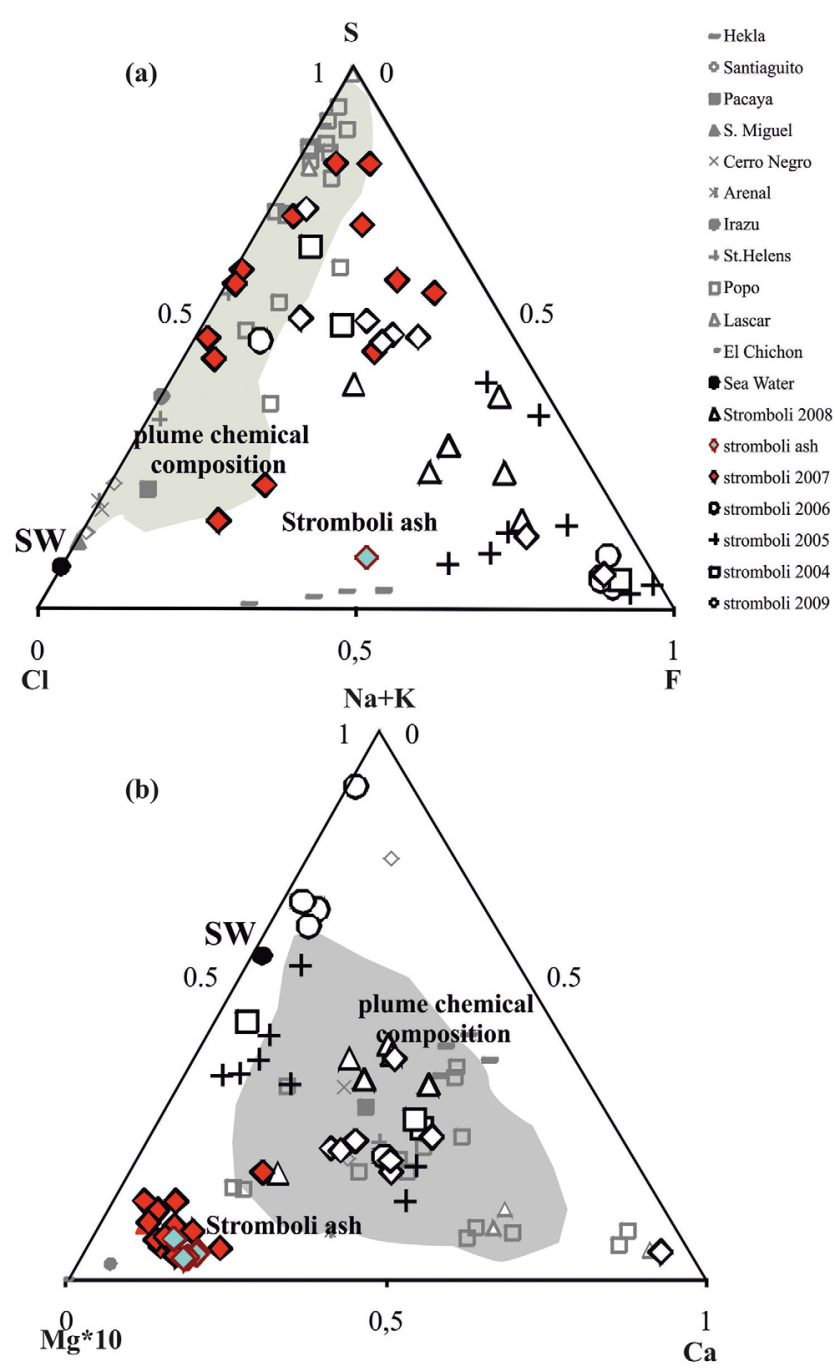

Figure 6. Ternary plots of relative adsorbed anions and cations concentrations in ash-leachate solutions from Stromboli samples. (a) Ash leachates are in most cases far richer in $\mathrm{F}$ (relative to $\mathrm{S}$ and $\mathrm{Cl}$ ) than the bulk plume, implying that gas-ash interactions must be gas-specific $\left(\mathrm{HF}_{\mathrm{g}}\right.$; see section 5.3). (b) Leachates show a large spread of cation species composition: the 2007 ash samples overlap the average composition of Stromboli's bulk ash, while the remaining (2004 to 2009) samples have distinct cation compositions, suggesting that condensation of plume volatiles (on ash particles) dominate the cation budget. Concentrations of various volcanic activities are also plotted for comparison. Literature data sources are the same as Figure 5. The grey areas correspond to the plume's chemical composition.

We argue then that either ash-acidic gas reactions in the plume were not isochemical (e.g., alkalis and $\mathrm{Ca}$ were more effectively extracted from ash than $\mathrm{Mg}$, the latter thus ultimately becoming depleted in ash leachates), or that condensation of plume volatiles (on ash particles) dominated the cation budget. It is known, in fact, that metal-bearing aerosol particles, formed by condensation of a gaseous precursor, are more enriched in $\mathrm{Na}, \mathrm{K}$, and $\mathrm{Ca}$ with respect to less volatile
Mg [Allard et al., 2000]. Finally, seawater spray contribution cannot be excluded for some alkali-rich (and $\mathrm{Ca}$-poor) samples.

\subsection{Insights into the Mineralogy of Water-Soluble Materials}

[22] Whatever their origin, either from acid dissolution of ash particles or from condensation of plume gases, a variety of chemicals are deposited as mineral films on the surface of ash grains, before being finally extracted during our leaching experiments. These mineral incrustations are often submicron sized, irregularly shaped, and heterogeneous in composition and are as such difficult to characterize with conventional microscope techniques (e.g., scanning electron microscope, SEM). Indirect information on their mineralogical properties can however be derived from scatterplots correlating the molar abundances of cation and anion species in ash leachates [Rose, 1977; Hinkley and Smith, 1987; de Hoog et al., 2001; Risacher and Alonso, 2001] (Figure 5). Our results, in particular, demonstrate that $\mathrm{Na}$ and $\mathrm{Cl}$ in Stromboli's ash leachates correlate strongly $\left(r^{2}=0.6\right.$ ) (Figure $5 b$ ), as do $\mathrm{Ca}$ and $\mathrm{SO}_{4}\left(r^{2}=0.8\right)$ (Figure $5 \mathrm{c}$ ). Using the relative metal-to-anion proportions in ash leachates, we derive information on the stoichiometry of the most abundant water-soluble surface materials, showing that $\mathrm{CaSO}_{4}$ (hydrated?) and $\mathrm{NaCl}$ are likely the prevalent soluble salts coating ash surfaces (and thus being leached during our experiments). $\mathrm{CaSO}_{4}$ and halite were repeatedly observed by SEM on Stromboli's ash surfaces (this study and Lautze et al. [2011]), and both mineral phases have commonly been reported as incrustations on ash particles at many active volcanoes [Rose et al., 1973; Heiken, 1972]. As a most notable example, SEM observations on ash samples from Mt. St. Helens revealed the peculiar association of $\mathrm{NaCl}-\mathrm{KCl}$ cubes [Woods et al., 1985; Varekamp et al., 1986] and anhydrite/gypsum incrustations [Thomas and Buseck, 1983]. Overall, the high correlations in Figures 5b and $5 \mathrm{c}$ also indicate that either the sources of cations and anions in ash leachates are the same (e.g., direct condensation of $\mathrm{NaCl}_{\mathrm{g}}$ and $\mathrm{CaSO}_{4 \mathrm{~g}}$ from the plume, or remobilization of $\mathrm{NaCl}_{(\mathrm{s})}$ and $\mathrm{CaSO}_{4(\mathrm{~s})}$ from the hydrothermal envelop [Varekamp et al., 1986]); or, more probably, that the higher the availability of acidic gases $\left(\mathrm{SO}_{2 \mathrm{~g}}\right.$ and $\left.\mathrm{HCl}_{\mathrm{g}}\right)$ in the plume, the more favorable the extraction of cations from dissolving ash fragments, followed by precipitation of $\mathrm{CaSO}_{4(\mathrm{~s})}$ and $\mathrm{NaCl}_{(\mathrm{s})}$ on ash surfaces [Rose, 1977; Oskarsson, 1980; Hinkley and Smith, 1982; Delmelle et al., 2007]. With the same line of reasoning, we observe that the positive high correlations between $\mathrm{Mg}$ and $\mathrm{SO}_{4}$ (Figure $5 \mathrm{~d}$ ), $\mathrm{K}$ and $\mathrm{Cl}$ (Figure 5e) and $\mathrm{Al}$ and $\mathrm{SO}_{4}$ (not shown) may indicate that $\mathrm{MgSO}_{4(\mathrm{~s})}, \mathrm{KCl}_{(\mathrm{s})}$ and $\mathrm{Al}_{2}\left(\mathrm{SO}_{4}\right)_{3(\mathrm{~s})}$, while not directly detected by SEM observations at Stromboli, were among the components of the water-soluble surface materials, as they are at other volcanoes (e.g., El Chichòn, Fuego, and Mt. St. Helens [Taylor and Stoiber, 1973; Varekamp et al., 1984, 1986; Woods et al., 1985; Hinkley and Smith, 1987]).

[23] Glass dissolution reactions are strongly enhanced by the presence of $\mathrm{HF}_{\mathrm{g}}$ in the core of the eruptive plume [Moune et al., 2006; Bellomo et al., 2007; D'Alessandro et al., 2008], to the point that minerals such as $\mathrm{CaF}_{2(\mathrm{~s})}, \mathrm{AlF}_{3(\mathrm{~s})}$ and $\mathrm{MgF}_{2(\mathrm{~s})}$ are thought to form on the surface of ash as a result of exposure to the plume at temperatures $>700^{\circ} \mathrm{C}$ [ Oskarsson, 


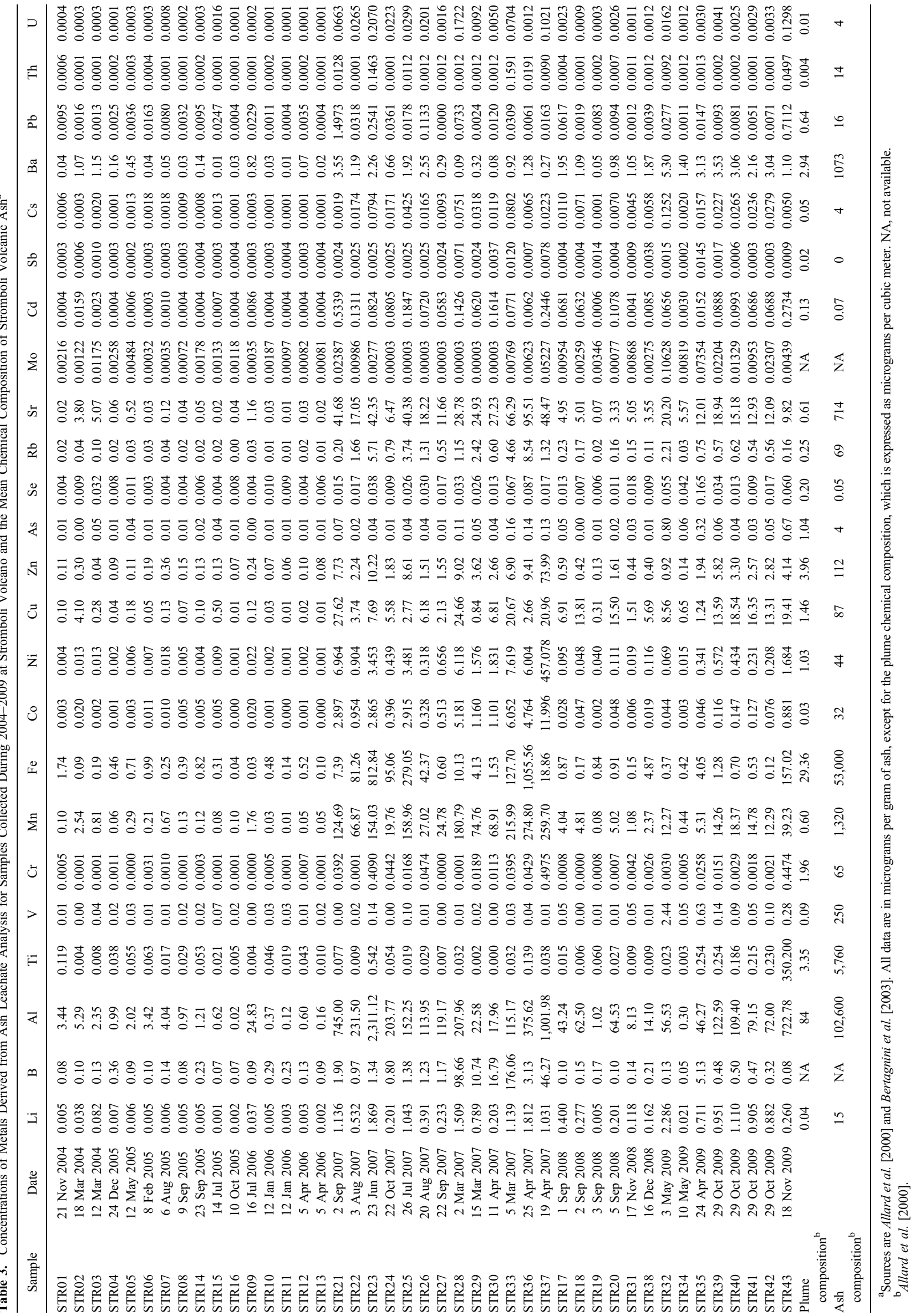




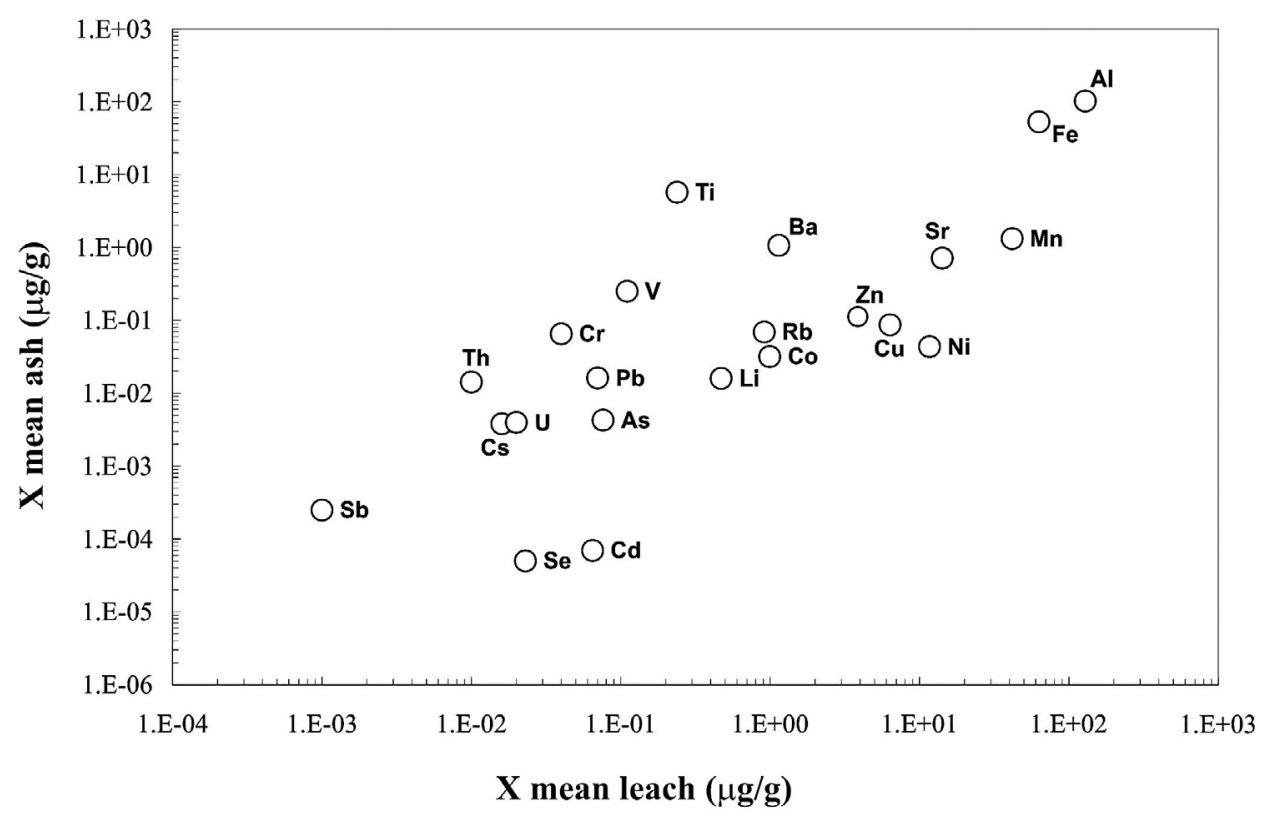

Figure 7. Diagram that shows the good correlation between trace element abundances in ash leachates and the corresponding abundances in the source magmas.

1980]. At Stromboli, the presence of these phases in the water-soluble mineral paragenesis cannot be excluded (most major cation concentrations in ash leachates are indeed positively correlated with F contents; Figure 5f). We note, however, that metal to $\mathrm{F}$ proportions in ash leachates seem to argue against that major cations are prevalently associated with fluorides; for example, $\mathrm{Ca} / \mathrm{F}$ ratios in Stromboli's ash leachates are different from what would be expected, if congruent dissolution of stoichiometry fluorite was a major process taking place during our leaching experiments (Figure 5f).

\subsection{Trace Metals and Enrichment Factors}

[24] The concentrations of a suite of trace elements in our ash leachates samples are reported in Table 3 . These range from about $0.0001 \mu \mathrm{g} / \mathrm{g}$ for ultra-trace elements (e.g., $\mathrm{Sb}$, $\mathrm{Se}, \mathrm{Th}, \mathrm{U}$ ) to $>1,000 \mu \mathrm{g} / \mathrm{g}$ for major elements (e.g., $\mathrm{Mn}, \mathrm{Al}$, $\mathrm{Fe}, \mathrm{Ti})$.

[25] Broadly speaking, trace element abundances in ash leachates correlate well with the corresponding abundances in the source ash (Figure 7). Element-to-element fractionations (relative to magma) are observed (Figure 8): This is not surprising, considering the contrasting metal affinities for the magmatic vapor phase [McKenzie and Canil, 2008], and the different mobilities of trace metals upon acid attack of basalts [Aiuppa et al., 2000]. To determine which elements are more enriched in ash leachates solutions (relative to ash composition), we calculated, for each X element, the enrichment factor (EF), based upon the relation [Zoller et al., 1983]:

$$
\mathrm{EF}=(\mathrm{X} / \mathrm{Ti})_{\text {leachate }} /(\mathrm{X} / \mathrm{Ti})_{\text {ash }}
$$

[26] The enrichment factor allows assessing the extent to which any given element is enriched in ash leachates relative to a reference element (Ti). An EF close to unity indicates there is essentially no enrichment occurring for a given element in water-soluble form relative to the expected abundance in the pristine ash.

[27] Since Ti is a poorly volatile element at magmatic conditions, and also one of the most immobile elements during the weathering of basalts [Aiuppa et al., 2000], EFs far exceeding unity characterize volatile (enriched in the plume because of their affinity for the magmatic vapor phase) and/or mobile (more readily leached than Ti during acid-mediated leaching of ash) elements. Calculations show that the most enriched elements in the extract solutions, relative to $\mathrm{Ti}$ and bulk ash composition, are $\mathrm{F}, \mathrm{Cl}$, and $\mathrm{S}$, and, among trace elements, $\mathrm{Se}, \mathrm{Cd}$ and $\mathrm{Cu}(\mathrm{EF} \gg 1$; Figure 8). Similar results have been previously documented by ash leachate analysis from many other active volcanoes [Smith et al., 1982; Stoiber and Rose, 1974; Oskarsson, 1980; Phelan-Kotra et al., 1983]. Enriched trace elements display significant correlations either with sulfate $(\mathrm{Cu}$; Figure $9 \mathrm{a})$ or chloride $(\mathrm{Cd}, \mathrm{Zn}$; Figure $9 \mathrm{~b}$ ), and there is a similarity of $\mathrm{Cu} / \mathrm{S}$ and $\mathrm{Zn} / \mathrm{Cl}$ ratios in plume and ash leachates (Figure 9). It follows then that enrichment in ash leachate may reflect trace metal degassing and plume transport as gaseous halides and $\mathrm{S}$ compounds (e.g., $\mathrm{CuS}_{\mathrm{g}}, \mathrm{ZnCl}_{2 \mathrm{~g}}$ [Krauskopf, 1964; Naughton et al., 1974; Moune et al., 2006; Varekamp et al., 1986]), before deposition upon ash surfaces. Besides, the positive dependence between $\mathrm{Mg}$ and $\mathrm{Ni}$ contents in leachate solutions claims for the role played by leaching of forsteritic olivine as main source of chemicals to our samples (Figure 9d).

[28] Elements like $\mathrm{Fe}, \mathrm{Cr}, \mathrm{Th}, \mathrm{Ba}, \mathrm{Al}$, and $\mathrm{V}$, instead, have EFs close to unity (Figure 8 ). These elements are known for having low affinity for the vapor phase during magmatic degassing and for their poor mobility during basalt leaching [Aiuppa et al., 2000]. Low-EF trace metals have concentrations that correlate well with $\mathrm{F}$ (see the Ba versus F plot of 


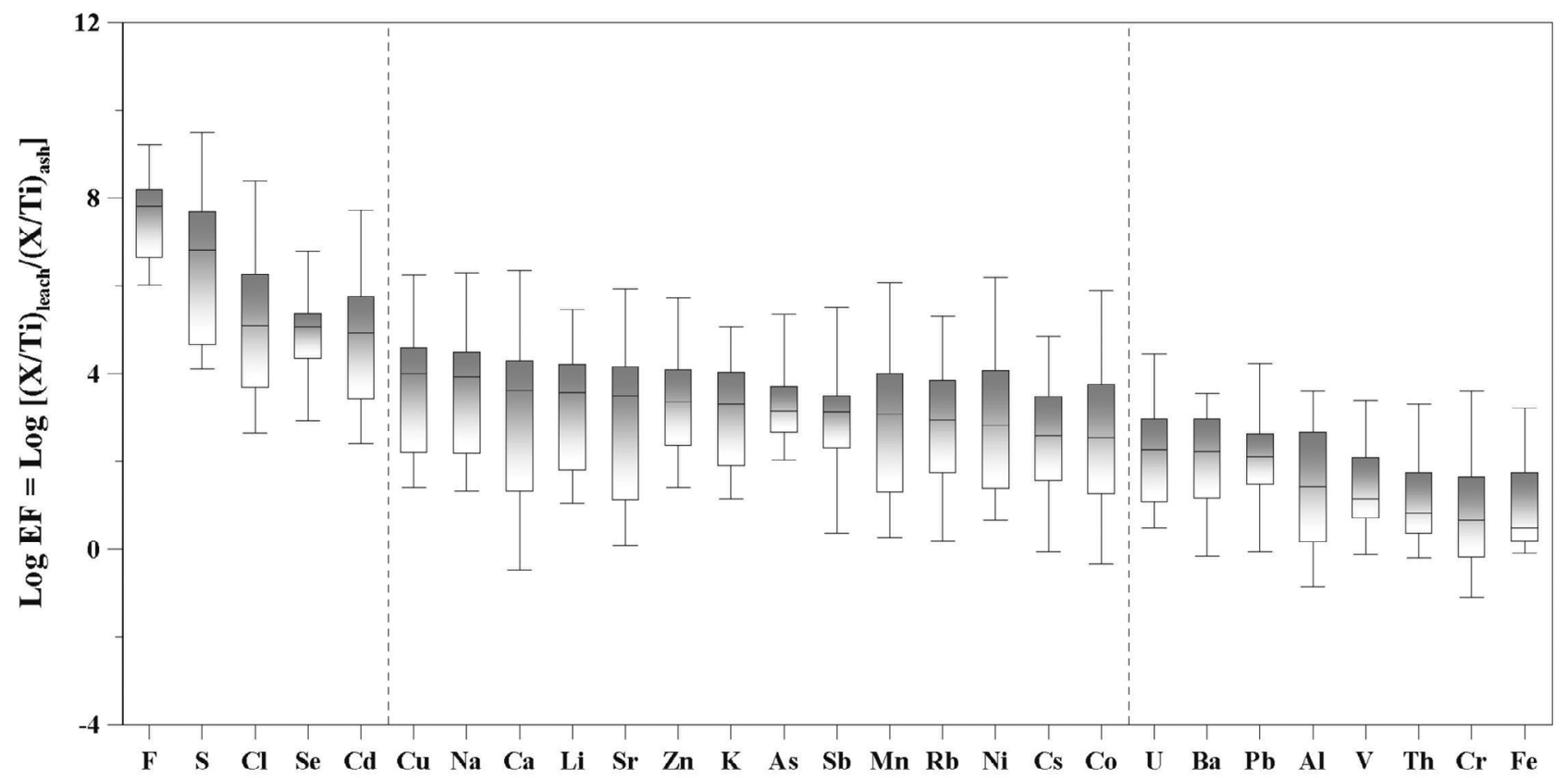

Figure 8. Diagram shows the element-to-element fractionations relative to magma due to the contrasting metal affinities for the magmatic vapor phase. Our data show that the most enriched elements in the extract solutions are $\mathrm{F}, \mathrm{Cl}$, and $\mathrm{S}$; and among trace elements, $\mathrm{Se}, \mathrm{Cd}$, and $\mathrm{Cu}(\mathrm{EF} \gg 1)$.
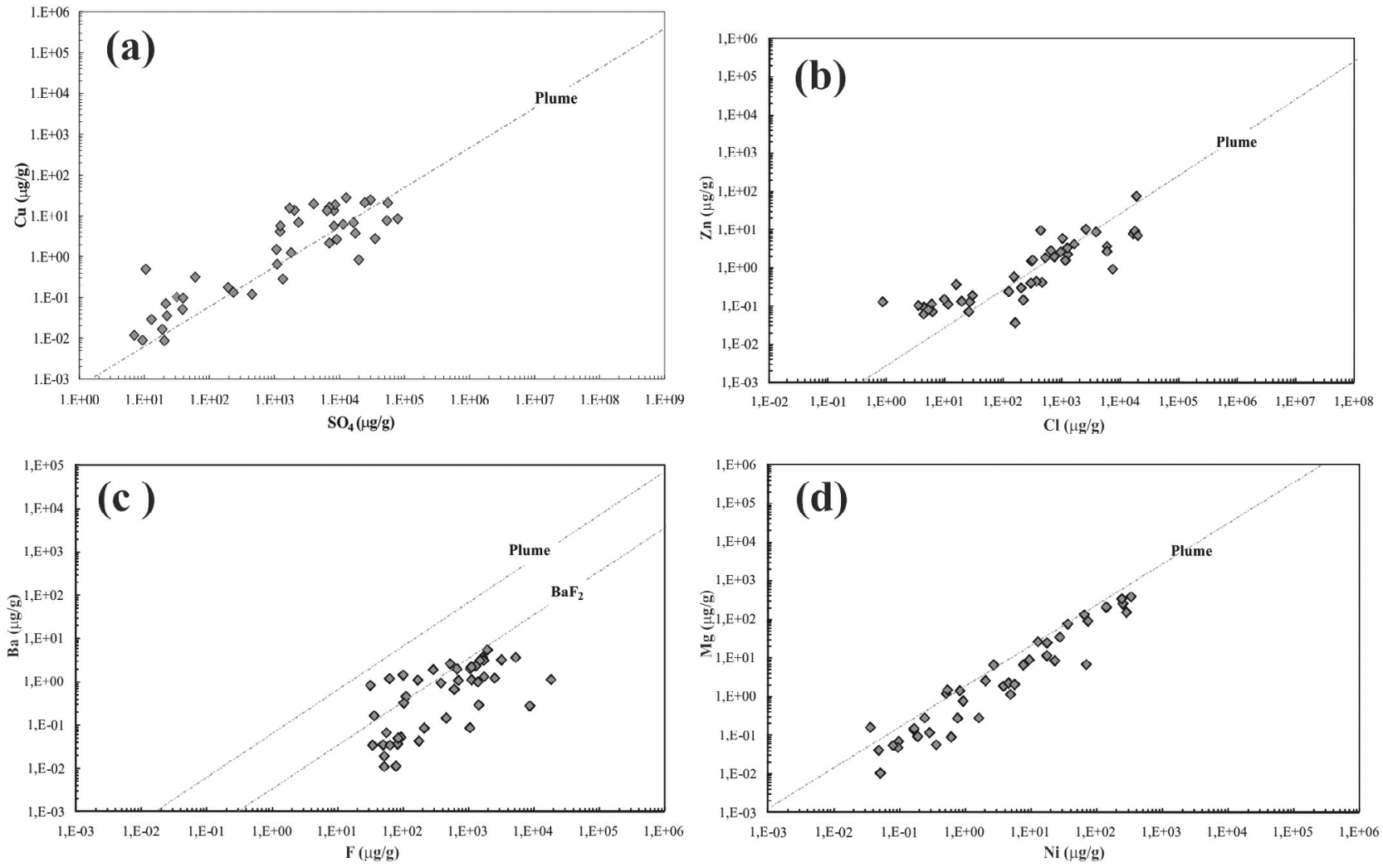

Figure 9. Binary plots displaying significant correlations either with (a) sulfate, (b) chloride, (c) fluoride, and (d) $\mathrm{Ni}$, suggesting both that the enrichment in ash leachate may reflect trace metal degassing and plume transport as gaseous halides and $\mathrm{S}$ compounds, and that the $\mathrm{HF}_{\mathrm{g}}$ adsorption on ash particles is a key factor regulating the release of low EF trace metals from silicates to the water-soluble surface material. Besides, the positive dependence between $\mathrm{Mg}$ and $\mathrm{Ni}$ contents in leachate solutions suggests the role played by leaching of forsteritic olivine as the main source of chemicals in our samples. 


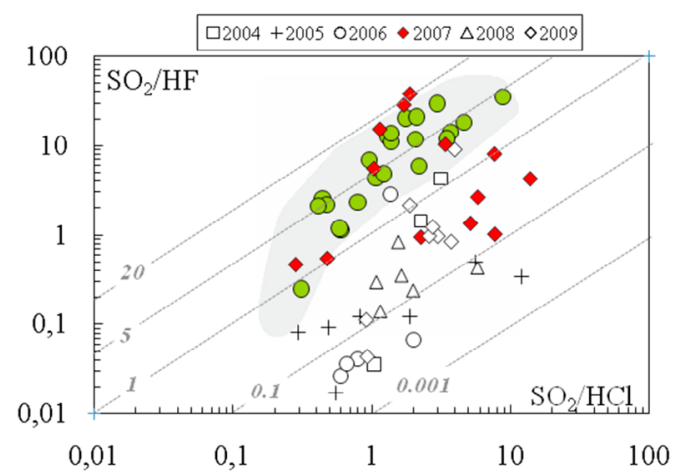

Figure 10. $\mathrm{S} / \mathrm{Cl}$ variation with $\mathrm{S} / \mathrm{F}$ molar ratio for leachate solutions from Stromboli 2004-2009 eruptions. Green circles and the gray area indicate Stromboli's plume chemical composition. The dashed diagonal lines represent $\mathrm{Cl} / \mathrm{F}$ ratios of $0.001,0.1,1,5$, and 20. Most of the data show $\mathrm{Cl} / \mathrm{F}$ ratios from 0.001 to 1 , which are far below the accepted volcanic arc gas range (1.9-160 [Aiuppa et al., 2009]). Plume chemical composition is from a personal communication with A. Aiuppa (2010).

Figure 9c), which may suggest that $\mathrm{HF}_{\mathrm{g}}$ adsorption on ash particles is a key factor governing their release from silicates to water-soluble surface materials.

\section{Discussion: Implications for Volcano Monitoring}

\subsection{Stromboli's Ash Leachates as Representative of the Volcanic Gas Plume?}

[29] The highly heterogeneous composition of Stromboli's ash leachates is a hint for the complexity (and time variability) of processes governing the formation of water-soluble materials adhering onto volcanic ash surfaces [Delmelle et al., 2007]. Our chemical characterization, though not exhaustive, provides evidence that several processes are concurrently active in the plume, among which (i) gas condensation onto fresh ash surfaces, (ii) leaching of ash constituents by acidic gases, and (iii) entrainment in the plume of detrital (lithic) S-Cl-bearing fragments, are likely the most significant. It is clear then (Figure 6) that ash leachate compositions are not representative of any single process but will reflect the combined (mutual) action of all of them. For ash leachates to valuably assist in volcano hazard assessment, however, a clear identification of their source processes is mandatory, and to understand the extent to which ash leachates are a proxy of plume composition is highly critical.

[30] Of the plume volatiles that may potentially be investigated using ash leachates, $\mathrm{S}$ and halogens are obviously the most attractive. As basaltic magmas are decompressed through the upper crust, these species will be selectively partitioned into the gas phase (with $\mathrm{S}$ being first separated from melts relative to more soluble $\mathrm{Cl}$ and $\mathrm{F}$; Métrich et al. [2010]) so that $\mathrm{SO}_{2} / \mathrm{HCl}$ and $\mathrm{SO}_{2} / \mathrm{HF}$ ratios in volcanic gas discharges have been taken as useful parameters to explore the mechanisms of magmatic degassing [Aiuppa et al., 2009] to identify depths of gas-melt separation [Allard et al., 2005; Burton et al., 2007] and eventually to predict patterns in a volcano's behavior [Aiuppa et al., 2002]. Therefore, $\mathrm{S} / \mathrm{Cl}$ ratios have been analyzed in ash leachates from a variety of volcanic eruptions in different contexts, based on the guess (yet often not entirely demonstrated) that they are representative of the plume $\mathrm{SO}_{2} / \mathrm{HCl}$ ratios. Results have shown that high $\mathrm{S} / \mathrm{Cl}$ ratios are often associated with large-scale explosive eruptions, including the 1974 Fuego eruption $(\mathrm{S} / \mathrm{Cl}$ ratios $>4$ [Rose, 1977]), the 1982 eruption of El Chichón $(\mathrm{S} / \mathrm{Cl}$ ratios $\sim 9$ [Varekamp et al., 1984]), and the 1982 Galunggung eruption (S/Cl ratios of $\sim 7-8$ [de Hoog et al., 2001]). These unusually high $\mathrm{S} / \mathrm{Cl}$ ratios $(\mathrm{S} / \mathrm{Cl}$ ratios of $<1$ have conversely been reported in ash leachates from passively degassing to mildly explosive volcanoes [Taylor and Stoiber, 1973]) have been interpreted as reflecting the sudden release of a sulfur-rich vapor phase, accumulated within the magma body prior to eruption, or from the influx of primitive sulfur-rich magma shortly before eruptions [Roggensack et al., 1996; de Hoog et al., 2001].

[31] If the preceding considerations were to apply to our Stromboli data set, we would then expect to see the largest ash leachate $\mathrm{S} / \mathrm{Cl}$ values associated with the 15 March 2007 paroxysm and the 3 May 2009 major explosions, the only events (at least during our investigated period) during which the S-rich [Métrich et al., 2010] basaltic (LP) magma has been erupted. However, while both model calculations [Allard, 2010] and gas-phase observations [Aiuppa and Federico, 2004] support that a high $\mathrm{S} / \mathrm{Cl}$ ratio gas phase may be associated with the ascent of the LP magma, no evidence for this is found in our ash leachate data set (Table 2): the highest $\mathrm{S} / \mathrm{Cl}$ ratios are observed, instead, in ash leachates from May-August 2005 (a period of relatively "ordinary" Strombolian activity) and late April-August 2007 (the period following the 2007 effusive unrest, during which even the "ordinary" Strombolian activity had virtually ceased or was, after late June, slowly resuming).

[32] The observations above clearly raise a question on whether or not Stromboli's ash leachates have truly representative compositions of the volcanic gas plume. The $\mathrm{S} / \mathrm{Cl}$ versus $\mathrm{S} / \mathrm{F}$ scatterplot of Figure 10 indicates, in fact, that only a few ash leachate samples, intriguingly all collected during the 2007 effusive unrest and in coincidence with the March 15th paroxysm, have $\mathrm{S}: \mathrm{Cl}: \mathrm{F}$ compositions consistent with the plume chemical signature, whereas all the remaining samples, though having $\mathrm{S} / \mathrm{Cl}$ ratios within the plume range, show far too small $\mathrm{S} / \mathrm{F}$ ratios. These samples display $\mathrm{Cl} / \mathrm{F}$ ratios of 0.001 to 1 (Figure 10), far below the accepted volcanic arc (and Stromboli's) gas range (1.9-160; [Aiuppa et al., 2009]). We conclude that since $\mathrm{S} / \mathrm{F}$ and $\mathrm{Cl} / \mathrm{F}$ ratios in ash leachates are in no way representative of plume composition (except in March 2007), then also S/Cl ratios may also not be representative: The high $\mathrm{S} / \mathrm{Cl}$ ratios in ash leachates from May to August 2005 and late April to August 2007 may thus not reflect a high $\mathrm{SO}_{2} / \mathrm{HCl}$ gas plume (for which there would be no obvious volcanological explanation) and may require a different explanation. In particular, we observe (Table 1) that high $\mathrm{S} / \mathrm{Cl}$ ratios in ash leachates were systematically measured in samples (e.g., STR05, STR26) in which significant (larger than usual) amounts of secondary gypsum crystals were revealed by microscopic (binocular, SEM) observations; these crystals were in most cases large $(0.1-$ $0.5 \mathrm{~mm}$ ), tabular, and angular, suggesting they mostly consisted in lithic fragments possibly recycled from the conduit/ hydrothermal envelop. We conclude that, in samples where a 


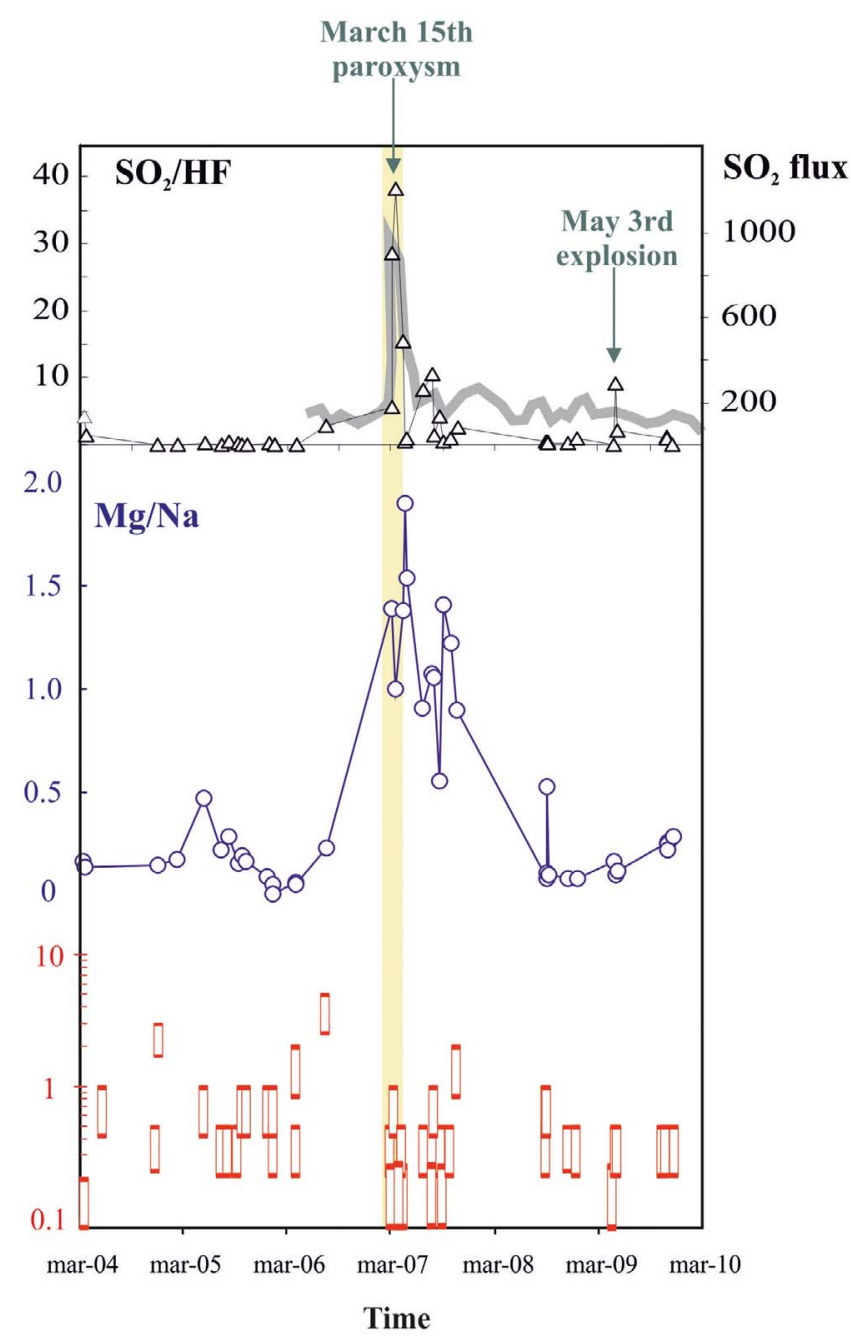

Figure 11. Time series diagrams of $\mathrm{SO}_{2} / \mathrm{HF}$ (top left of plot) and $\mathrm{Mg} / \mathrm{Na}$ molar ratios (center of plot) at Stromboli. $\mathrm{SO}_{2}$ flux (metric ton per day) data are also reported (top right of plot) and the report of the ash emission episodes at Stromboli volcano during the period of investigation are also described (bottom of plot). The diagrams show that ash leachate compositions respond to the variation in the degassing regime prior to the 15 March 2007 and 3 May 2009 explosions, with higher $\mathrm{S} / \mathrm{F}$ and $\mathrm{Mg} / \mathrm{Na}$ ash leachate molar ratios (see section 6.2). The yellow area indicates the period characterized by paroxysmal explosions (from 5 March to 15 March 2007).

detrital S contribution becomes significant (or even prevails), the ash leachate $\mathrm{S}: \mathrm{F}: \mathrm{Cl}$ compositions are clearly insensitive to (and are thus in no way representative of) plume compositional signature.

\subsection{The Exceptional 2007 Activity of Stromboli}

[33] Accepting that, at least at Stromboli, ash leachate S:Cl:F compositions only marginally reflect the composition of the plume, the next open question is Which peculiar conditions persisted over February-March 2007, to determine the unusual "plume-like" compositions of ash leachates (Figure 10) in that interval? Indeed, in the time series diagrams of Figure 11, the unusual compositional features of ash leachates relative to the 2007 unrest clearly stand out. We observe that, as the effusive eruption started on 27 February 2007, ash leachates became abnormally S-rich and F-poor (Figure 6a): the S/F ratio, which had systematically remained $<2$ during the 2004-2006 period, increased to 5.6 (within the typical plume range; Figure 10) on 2 March, only 3 days after the eruption onset; to then peak at 29 on 5 March and 38 on 15 March (during the paroxysmal explosion). It was only after the 2007 effusive eruption had come to an end (on 2 April), that the $\mathrm{S} / \mathrm{F}$ ratio started to decrease, to return to its preeruption values $(<1$; far below the magmatic range) in summer 2008 (Figure 11a). This cycle of increase-decrease of the ash leachate $\mathrm{S} / \mathrm{F}$ ratio was mirrored by a parallel increase in $\mathrm{Mg}$ proportions (increasing $\mathrm{Mg} / \mathrm{F}$ - not shown - and $\mathrm{Mg} / \mathrm{Na}$ ratios, Figure 11b). All ash leachate samples collected in 2007, during and in the months after the eruption, were in fact characterized by an unusually Mg-rich composition (see Figure 6); this is in spite of the fact the composition (and particularly the Mg content) of the feeding magma in the volcano's upper conduits was remarkably constant (as evidenced by SEM-EDS measurements in matrix glasses from ash fragments and by bulk-rock measurements in lava flows sequentially emitted over the 27 February to 2 April 2007 interval [Landi et al., 2009]).

[34] The $\mathrm{SO}_{2}$ flux trend reported in Figure 11a (data from INGV-CT; courtesy T. Caltabiano) is probably a key to understanding the peculiar ash leachate features in 2007. We show in Figure 11 that the high $\mathrm{S} / \mathrm{F}$ and $\mathrm{Mg} / \mathrm{Na}$ ash leachate ratios in 2007 were all detected during a phase of unusually high degassing regime of the volcano, begun in coincidence with the onset of the effusive eruption on 27 February 2007 [Burton et al., 2009; Aiuppa et al., 2010a, 2010b]. This anomalous degassing phase, characterized by factor $\sim 3$ and $\sim 10$ increases in $\mathrm{SO}_{2}$ and $\mathrm{CO}_{2}$ fluxes from Stromboli's open vents, peaked shortly before the 15 March paroxysm [Aiuppa et al., 2010a, 2010b], persisted (though at declining rate) through the entire effusive phase, and then slowly vanished in the months following the eruption termination: This pattern entirely matches the trends shown by ash leachate compositions (Figure 11). We also point out that, throughout the entire 2007 degassing (and effusive) crisis, the "ordinary" Strombolian activity was not visible at the summit vents (Figure 4) and had been replaced by the intermittent (sporadic) emission of an unusually fine (Figure 11c) ash, rich in partially altered silicate fragments (overall suggesting that Strombolian activity was more sporadic, less energetic, and confined deep in the conduit) (cf. Sections 2 and 5.1).

[35] We propose that all the preceding observations are consistent with a model in which gas/ash relative proportions in the plume govern the compositional features of ash leachates. We observe that, during the 2007 Stromboli's unrest, the emission rates of $\mathrm{SO}_{2}$ (and other acid gases) were anomalously high, whereas the production of ash (and its later transport in the plume) was unusually low (no visible Strombolian activity at the summit vents). In such conditions (in a high gas/ash ratio plume), gas-ash interactions may be thought to be higher than usual, to the point that ash leachate $\mathrm{S}: \mathrm{Cl}: \mathrm{F}$ compositions will be wholly representative of the composition of the gas plume (Figure 10) (yielding to an overall increase of the $\mathrm{S} / \mathrm{F}$ ash leachate ratio). In addition, the larger (than usual) acidic gas condensation on ash fragments would promote their extensive leaching, leading to cation release in nearly similar amounts as in the dis- 
solving ash (isochemical ash leaching): This would produce the unusually $\mathrm{Mg}$-rich composition of the 2007 ash leachate samples (Figures 5d, 6a, 11b, and 11c). We speculate that these processes (more gas condensation on ash surfaces, and more extensive gas-ash interaction) may also have been favored by the usually fine nature of ash emitted during the 2007 unrest (Figure 11c), contributing to an increased surface area for water-aerosol adsorption [Delmelle et al., 2005], and consequently the occurrence of gas-ash reactions.

[36] In contrast, during the "ordinary" Strombolian activity phases, gas fluxes will be 3-10 times lower, whereas in-plume ash contents will be higher because of persistent spattering and Strombolian explosions at the summit vents: our data suggest that, in such low gas/ash ratio plumes, gas deposition on ash will become gas-specific (with $\mathrm{HF}_{\mathrm{g}}$ being selectively scavenged by ash, leading to lower-than-plume $\mathrm{S} / \mathrm{F}$ and $\mathrm{Cl} / \mathrm{F}$ ratios; Figure 10 ); in addition, ash fragments will be less prone to leaching, so that more mobile cations ( $\mathrm{Na}, \mathrm{K}$ and $\mathrm{Ca}$ ) will be more easily extracted than $\mathrm{Mg}$, leading to low $\mathrm{Mg} / \mathrm{Na}$ ratios in ash leachates (Figure 6a and 11b). We finally note, however, that a minor (relative to 15 March 2007) but still detectable increase of the ash leachate $\mathrm{S} / \mathrm{F}$ ratios was measured in the 3 May 2009 ash sample, collected just $3 \mathrm{~h}$ prior to a major explosion (Figure 11a). This implies that, even during ordinary activity phases, the precursory gas flux increases, which systematically occur prior to larger-scale explosive events [Aiuppa et al., 2010a, 2010b, and manuscript in preparation, 2011], may leave a distinct compositional sign in ash leachates.

\section{Conclusions}

[37] At Stromboli volcano, the composition of the ash leachates may show strong differences and are time variable, thus suggesting a multiplicity of source processes. We retain that while condensation of gaseous species on ash particles undoubtedly plays a key control on the formation of surface soluble materials, the composition of the latter is only marginally (and temporarily) representative of the original plume composition, because (i) gas-ash interactions are apparently gas-specific (with $\mathrm{HF}_{\mathrm{g}}$ being preferentially scavenged by ash); (ii) soluble salts may also (at least partially) derive from acid-mediated leaching of ash, and (iii) additional sulfur (and possibly other species) may be contributed from entrainment in the gas plume of detrital (lithic) mineral fragments, possibly derived from the hydrothermal envelop or from the altered conduit walls (e.g., hydrothermal sulfates). We conclude that ash leachate compositions at Stromboli (and possibly other open-vent volcanoes) are related to volcanic activity state in a highly complex and nonlinear manner. Hence, they are affected by a variety of factors, including gas emission rates, plume ash content, ash componentry, and texture (all depending on the prevailing eruptive style). It is only in peculiar activity periods, when gas emissions are particularly large and ash production unusually low (e.g., in the gas-rich and ash-poor plumes emitted during the Stromboli's February-April 2007 unrest), that ash leachates apparently become proxies for plume composition. In spite of these complexities, however, we observe that ash leachate compositions promptly responded (with a net increase of the $\mathrm{S} / \mathrm{F}$ ratio) to the variation in degassing regime occurring prior to the 15 March 2007 and 3 May 2009 explosions (the most sizable explosive events during our investigated period) (Figure 11). Whereas our conclusions are based on post-hoc data analysis, we thus suggest that systematic ash observations in the future may become helpful in revealing any eventual departure from Stromboli's ordinary activity state, potentially preceding hazardous large-scale explosive events.

[38] Acknowledgments. This work was partially funded by the Italian Dipartimento della Protezione Civile within the frame of the 2007-2009 Agreement with INGV (Project V2 Paroxysm). We are strongly grateful to personnel from Italian Civil Defense for logistic help and Volcanological Guides of Stromboli for field support during all the activities carried out in the last years at Stromboli.

\section{References}

Aiuppa, A., and C. Federico (2004), Anomalous magmatic degassing prior to the 5th April 2003 paroxysm on Stromboli, Geophys. Res. Lett., 31, L14607, doi:10.1029/2004GL020458.

Aiuppa, A., P. Allard, W. D’Alessandro, A. Michel, F. Parello, M. Treuil, and M. Valenza (2000), Mobility and fluxes of major, minor and trace metals during basalt weathering at Mt. Etna volcano (Sicily), Geochim. Cosmochim. Acta, 64, 1827-1841, doi:10.1016/S0016-7037(00)00345-8.

Aiuppa, A., C. Federico, A. Paonita, G. Pecoraino, and M. Valenza (2002),

S, Cl and F degassing as an indicator of volcanic dynamics: The 2001 eruption of Mount Etna, Geophys. Res. Lett., 29(11), 1559, doi:10.1029/ 2002 GL015032.

Aiuppa, A., C. Federico, G. Giudice, G. Giuffrida, R. Guida, S. Gurrieri, M. Liuzzo, R. Moretti, and P. Papale (2009), The 2007 eruption of Stromboli volcano: Insights from real-time measurement of the volcanic gas plume $\mathrm{CO}_{2} / \mathrm{SO}_{2}$ ratio, Volcanol. Geotherm. Res., 182, 221-230, doi:10.1016/j.jvolgeores.2008.09.013.

Aiuppa, A., M. Burton, T. Caltabiano, G. Giudice, S. Guerrieri, M. Liuzzo, F. Mur, and G. Salerno (2010a), Unusually large magmatic $\mathrm{CO}_{2}$ gas emissions prior to a basaltic paroxysm, Geophys. Res. Lett., 37 , L17303, doi:10.1029/2010GL043837.

Aiuppa, A., A. Bertagnini, N. Métrich, R. Moretti, A. Di Muro, M. Liuzzo, and G. Tamburello (2010b), A model of degassing for Stromboli volcano, Earth Planet. Sci. Lett., 295, 195-204, doi:10.1016/j.eps1.2010.03.040.

Allard, P. (2010), $\mathrm{A} \mathrm{CO}_{2}$-rich gas trigger of explosive paroxysms at Stromboli basaltic volcano, Italy, J. Volcanol. Geotherm. Res., 189, 363-374, doi:10.1016/j.jvolgeores.2009.11.018

Allard, P., J. Carbonnelle, N. Metrich, H. Loyer, and P. Zettwoog (1994), Sulphur output and magma degassing budget of Stromboli volcano, Nature, 368, 326-330, doi:10.1038/368326a0.

Allard, P., A. Aiuppa, H. Loyer, F. Carrot, A. Gaudry, G. Pinte, A. Michel, and G. Dongarrà (2000), Acid gas and metal emission rates during longlived basalt degassing at Stromboli volcano, Geophys. Res. Lett., 27(8), 1207-1210, doi:10.1029/1999GL008413.

Allard, P., M. Burton, and F. Murè (2005), Spectroscopic evidence for a lava fountain driven by previously accumulated magmatic gas, Nature, 433, 407-410, doi:10.1038/nature03246.

Allard, P., A. Aiuppa, M. Burton, T. Caltabiano, C. Federico, G. Salerno, and A. La Spina (2008), Crater gas emissions and the magma feeding system of Stromboli volcano, in The Stromboli Volcano: An Integrated Study of the 2002-2003 Eruption, AGU Geophys. Monogr. Ser., vol. 182, edited by S. Calvari, S. Inguaggiato, M. Ripepe, and M. Rosi, pp. 65-80, AGU, Washington, D. C.

Andronico, D. (2009), Il parossismo eruttivo di Stromboli del 3 maggio 2009: Osservazioni di campagna svolte il giorno dopo. Internal Report UFVG2009/20,INGV, Sezione di Catania, Italy, available at http:// www.ct.ingv.it/Report/UFVG2009/20.pdf.

Andronico, D., and M. Pistolesi (2010), The November 2009 paroxysmal explosions at Stromboli, J. Volcanol. Geotherm. Res., 196(1-2), 120-125, doi:10.1016/j.jvolgeores.2010.06.005.

Andronico, D., A. Cristaldi, and J. Taddeucci (2007), Eruzione Stromboli 2007- L'evento parossistico del 15 marzo. Internal Report UFVG2007/ 016, available at http://www.ct.ingv.it/Report/RPTVSTRCEN20070315. pdf.

Andronico, D., R. A. Corsaro, A. Cristaldi, and M. Polacci (2008), Characterizing high energy eruptions at Stromboli volcano using multidisciplin- 
ary data: An example from the 9 January 2005 explosion, J. Volcanol. Geotherm. Res., 176, 541-550, doi:10.1016/j.jvolgeores.2008.05.011.

Armienta, M. A., A. L. Martin-Del Pozzo, R. Espinasa, O. Cruz, N. Ceniceros, A. Aguayo, and M. A. Burton (1998), Geochemistry of ash leachates during the 1994-1996 activity of Popocatepetl, Appl. Geochem., 13(7), 841-850, doi:10.1016/S0883-2927(98)00012-2.

Armienta, M. A., S. De la Cruz-Renya, O. Morton, O. Cruz, and N. Ceniceros (2002), Chemical variation of tephra-fall deposit leachates for three eruptions from Popocatepetl volcano, J. Volcanol. Geotherm. Res., 113, 61-80, doi:10.1016/S0377-0273(01)00251-7.

Barberi, F., M. Rosi, and A. Sodi (1993), Volcani hazard assessment at Stromboli based on review of historical data, Acta Vulcanol., 3, 173-187.

Barberi, F., L. Civetta, M. Rosi, and R. Scandone (2009), Chronology of the 2007 eruption of Stromboli and the activity of the Scientific Synthesis Group, J. Volcanol. Geotherm. Res., 182(3-4), 123-130.

Bellomo, S., A. Aiuppa, W. D’Alessandro, and F. Parello (2007), Environmental impact of magmatic fluorine emission in the Mt. Etna area J. Volcanol. Geotherm. Res., 165, 87-101, doi:10.1016/j.jvolgeores. 2007.04.013.

Bertagnini, A., M. Coltelli, P. Landi, M. Pompilio, and M. Rosi (1999), Violent explosions yield new insights into dynamic of Stromboli volcano, Eos Trans. AGU, 80(52), 633-636, doi:10.1029/99EO00415.

Bertagnini, A., N. Métrich, P. Landi, and M. Rosi (2003), Stromboli volcano (Aeolian Archipelago, Italy): An open window on the deep feeding system of a steady state volcano, J. Geophys. Res., 108(B7), 2336, doi:10.1029/2002JB002146.

Bonaccorso, A., C. Cardaci, M. Coltelli, P. Del Carlo, S. Falsaperla, S. Panucci, M. Pompilio, and L. Villari (1996), Volcanic activity on Stromboli in 1993, in Annual Report of the World Volcanic Eruptions in 1993, Bull. Volcanic Eruptions, 33, 7-13.

Burton, M., H. M. Mader, and M. Polacci (2007), The role of gas percolation in quiescent degassing of persistently active basaltic volcanoes, Earth Planet. Sci. Lett., 264, 46-60, doi:10.1016/j.eps1.2007.08.028.

Burton, M., T. Caltabiano, F. Murè, G. Salerno, and D. Randazzo (2009), $\mathrm{SO}_{2}$ flux from Stromboli during the 2007 eruption: Results from the FLAME network and traverse measurements, J. Volcanol. Geotherm. Res., 182, 214-220, doi:10.1016/j.jvolgeores.2008.11.025.

Calvari, S., L. Spampinato, L. Lodato, A. J. L. Harris, M. R. Patrick, J. Dehn, M. R. Burton, and D. Andronico (2005), Complex volcanic processes observed with a hand-held thermal camera during the 2002-2003 flank eruption at Stromboli volcano (Italy), J. Geophys. Res., 110, B02201, doi:10.1029/2004JB003129

Casadevall, T. J., W. I. Rose, W. H. Fuller, W. H. Hunt, M. A. Hart, J. L. Moyers, D. C. Woods, R. L. Chuan, and J. P. Friend (1984), Sulfur dioxide and particles in quiescent volcanic plumes from Poas, Arenal, and Colima volcanoes, Costa Rica and Mexico, J. Geophys. Res., 89(D6), 9633-9641, doi:10.1029/JDALE089iD06p09633.

Christenson, B. W. (2000), Geochemistry of fluids associated with the 1995-1996 eruption of Mt. Ruapehu, New Zealand: Signatures and processes in the magmatic-hydrothermal system, J. Volcanol. Geotherm. Res., 97(1-4), 1-30, doi:10.1016/S0377-0273(99)00167-5.

Coltelli, M., S. Falsaperla, P. Del Carlo, M. Pompilio, and A. Bonaccorso (1999), Volcanic, seismic and round deformation data concernine the Stromboli volcano in 1995, Suppl. Bull. Volcanic Eruptions, 35, 8-14.

Connor, C. B., L. Powell, J. Thomas, M. Navarro, and W. Strauch (1993), Comparison of volatile concentrations in three Cerro Negro, Nicaragua, Eruptions, paper presented at 50 Años Del Volcan Paricutin, Reunion Internacional Commemorativa, Inst. de Geogr. UNAM, Uruapan, Mexico.

Cronin, S. J., V. E. Neall, J. A. Lecointre, M. J. Hedley, and P. Loganathan (2003), Environmental hazards of fluoride in volcanic ash: A case study from Ruapehu volcano, New Zeland, J. Volcanol. Geotherm. Res., 121(3-4), 271-291, doi:10.1016/S0377-0273(02)00465-1.

D'Alessandro, W., S. Bellomo, and F. Parello (2008), Fluorine speciation in topsoils of three active volcanoes of Sicily (Italy), Environ. Geol, 56, 413-423, doi:10.1007/s00254-007-1179-7.

de Hoog, J. C. M., G. W. Koetsier, S. Bronto, T. Sriwana, and M. J. van Bergen (2001), Sulfur and chlorine degassing from primitive arc magmas: Temporal changes during the 1982-1983 eruptions of Galunggung (West Java, Indonesia), J. Volcanol. Geotherm. Res., 108, 55-83, doi:10.1016/S0377-0273(00)00278-X.

Delmelle, P., F. Villièras, and M. Palletier (2005), Surface area, porosity and water adsorption properties of fine ash particles, Bull. Volcanol., 67, 160-169, doi:10.1007/s00445-004-0370-x.

Delmelle, P., M. Lambert, Y. Dufrene, P. Gerin, and N. Oskarsson (2007), Gas/aerosol-ash interaction in volcanic plumes: New insights from surface analyses of fine ash particles, Earth Planet. Sci. Lett., 259, 159-170, doi:10.1016/j.epsl.2007.04.052.

de Moor, J. M., T. P. Fisher, D. R. Hilton, E. Hauri, and L. A. Jaffe (2005), Degassing at Anatahn volcano during the May 2003 eruption: Implica- tions from petrology, ash leachates, and $\mathrm{SO}_{2}$ emissions, J. Volcanol Geotherm. Res., 146, 117-138, doi:10.1016/j.jvolgeores.2004.11.034.

Edmonds, M., C. Oppenheimer, D. M. Pyle, and R. A. Herd (2003), Rainwater and ash leachate analysis as proxies for plume chemistry at Soufrière hills volcano, Montserrat, Geol. Soc. Spec. Publ., 213, 203-218.

Francalanci, L., S. Tommasini, S. Conticelli, and G. R. Davies (1999), Sr isotope evidence for short magma residence time for the 20th century activity at Stromboli volcano, Italy, Earth Planet. Sci. Lett., 167, 61-69, doi:10.1016/S0012-821X(99)00013-8.

Giudicepietro, F., L. D’Auria, M. Martini, R. Peluso, T. Caputo, W. De Cesare, M. Orazi, and G. Scarpato (2009), Changes in the VLP seismic source during the 2007 Stromboli eruption, J. Volcanol. Geotherm. Res., 182, 162-171, doi:10.1016/j.jvolgeores.2008.11.008.

Heiken, G. (1972), Morphology and petrography of volcanic ashes, Geol. Soc. Am. Bull., 83, 1961-1988, doi:10.1130/0016-7606(1972)83[1961: MAPOVA]2.0.CO;2.

Hinkley, T. K., and K. S. Smith (1982), Leachate chemistry of the tephra from the May 181980 eruption of Mount St. Helens, Eos Trans. $A G U, 63(45), 1143$

Hinkley, T. K., and K. S. Smith (1987), Chemistry of ash leachates from the May 18, 1980 eruption Mount St. Helens, Washington, U.S. Geol. Surv. Prof. Pap., 1397, 34 pp.

Horrocks, L. A., C. Oppenheimer, M. R. Burton, and H. J. Duffell (2003), Compositional variation in tropospheric volcanic gas plumes: Evidence from ground-based remote sensing, Geol. Soc. Spec. Publ., 213, 349-369.

Krauskopf, K. B. (1964), The possible role of metal compounds in ore genesis, Econ. Geol., 59, 22-45, doi:10.2113/gsecongeo.59.1.22.

Lacroix, A. (1907), Les mineraux des fumerolles de l'eruption du Vesuve en avril 1906, Bull. Soc. Mineral. Fr., 28, 219-266.

Landi, P., R. A. Corsaro, L. Francalanci, L. Civetta, L. Miraglia, M. Pompilio, and R. Tesoro (2009), Magma dynamics during the 2007Stromboli eruption (Aeolian Islands. Italy): Mineralogical, geochemical and isotopic data, J. Volcanol. Geotherm. Res., 182, 255-268, doi:10.1016/j.jvolgeores. 2008.11.010.

Lautze, D. (2011), D. SEM-based methods for the analysis of basaltic ash from weak explosive activity at Etna in 2006 and the 2007 eruptive crisis at Stromboli, Phys. Chem. Earth, in press.

Liotta, M., L. Brusca, F. Grassa, S. Inguaggiato, M. Longo, and P. Madonia (2006), Geochemistry of rainfall at Stromboli volcano (Aeolian Islands): Isotopic composition and plume-rain interaction, Geochem. Geophys. Geosyst., 7, Q07006, doi:10.1029/2006GC001288.

MacKenzie, J. M., and D. Canil (2008), Volatile heavy metal mobility in silicate liquids: Implications for volcanic degassing and eruption prediction, Earth Planet. Sci. Lett., 269, 488-496, doi:10.1016/j.epsl.2008.03.005.

Marchetti, E., and M. Ripepe (2005), Stability of the seismic source during effusive and explosive activity at Stromboli volcano, Geophys. Res. Lett., 32, L03307, doi:10.1029/2004GL021406.

Mather, T. M., D. M. Pyle, and A. G. Allen (2004), Volcanic source for fixed nitrogen in the early Earth's atmosphere, Geology, 32, 905-908, doi:10.1130/G20679.1

Métrich, N., A. Bertagnini, P. Landi, and M. Rosi (2001), Crystallisation driver by decompression and water loss at Stromboli volcano (Aeolian Islands), J. Petrol., 42(8), 1471-1490, doi:10.1093/petrology/42.8.1471.

Métrich, N., A. Bertagnini, P. Landi, M. Rosi, and O. Belhadj (2005), Triggering mechanism at the origin of paroxysms at Strombnoli (Aeolian Arcipelago, Italy): The 5 April 2003 eruption, Geophys. Res. Lett., 32, L10305, doi:10.1029/2004GL022257.

Métrich, N., A. Bertagnini, and A. Di Muro (2010), Conditions of magma storage, degassing and ascent at Stromboli: New insights into the Volcano Plumbing System with inferences on the eruptive dynamics, J. Petrol., 51(3), 603-626, doi:10.1093/petrology/egp083.

Moune, S., P. J. Gauthier, S. R. Gislason, and O. Sigmarsson (2006), Trace element degassing and enrichment in the eruptive plume of the 2000 eruption of Hekla volcano, Iceland, Geochim. Cosmochim. Acta, 70, 461-479, doi:10.1016/j.gca.2005.09.011.

Naughton, J. J., V. A. Lewis, D. Hammond, and D. Nishimoto (1974), The chemistry of sublimates collected directly from lava fountains at Kilauea volcano, Hawaii, Geochim. Cosmochim. Acta, 38, 1679-1690, doi:10.1016/0016-7037(74)90185-9.

Oskarsson, N. (1980), The interaction between volcanic gases and tephra: Fluorine adhering to tephra of the 1970 Hekla eruption, J. Volcanol. Geotherm. Res., 8, 251-266, doi:10.1016/0377-0273(80)90107-9.

Ossaka, J., and T. Ozawa (1975), Study on chemical compositions of volcanic gases and volcanic activity at Sakurajima volcano (in Japanese), in First Joint Observations of Sakurajima Volcano, pp. 62-66, Geogr. Surv. Inst., Kitasato, Japan.

Ossaka, J., K. Nogami, and J. Hirabayashi (1998), Water-soluble components on volcanic ashes from Tokachi-dake Volcano, Hokkaido, Japan, 
during the 1988-1989 eruption (in Japanese with English abstract), Bull. Volcanol. Soc. Jpn., 43, 25-31.

Patrick, M. R., A. J. L. Harris, M. Ripepe, J. Dehn, D. Rothery, and S. Calvari (2007), Strombolian explosive styles and source conditions: Insights from thermal (FLIR) video, Bull. Volcanol., 69(7), 769-784, doi:10.1007/ s00445-006-0107-0.

Phelan Kotra, J., D. L. Finnegan, W. H. Zoller, M. A. Hart, and J. L. Moyers (1983), El Chichòn: Composition of plume gases and particles, Science, 222, 1018-1021, doi:10.1126/science.222.4627.1018.

Pistolesi, M., M. Rosi, L. Pioli, A. Renzulli, A. Bertagnini, and D. Andronico (2008), The paroxysmal explosion and its deposits, in The Stromboli Volcano: An Integrated Study of the 2002-2003 Eruption, AGU Monogr. Ser., vol. 182, edited by S. Calvari et al., pp. 317-329, AGU, Washington, D. C.

Ripepe, M., E. Marchetti, G. Ulivieri, A. Harris, J. Dehn, M. Burton, T. Caltabiano, and G. Salerno (2005), Effusive to explosive transition during the 2003 eruption of Stromboli volcano, Geology, 33, 341-344, doi:10.1130/G21173.1.

Risacher, F., and H. Alonso (2001), Geochemistry of ash leachates from the 1993 Lascar eruption, northern Chile: Implication of ancient evaporities, J. Volcanol. Geotherm. Res., 109(4), 319-337, doi:10.1016/S0377-0273 (01)00198-6.

Rittmann, A. (1931), Der Ausbruck des Stromboli am 11 September 1930, Z. Vulkanol., 14, 47-77.

Roggensack, K., S. N. Williams, S. J. Schaefer, and R. A. Parnell Jr. (1996), Volatiles from the 1994 eruptions of Rabaul: Understanding large caldera systems, Science, 273, 490-493, doi:10.1126/science. 273.5274 .490

Rose, W. I. (1977), Scavenging of volcanic aerosol by ash: Atmospheric and volcanologic implications, Geology, 5, 621-624, doi:10.1130/ 0091-7613(1977)5<621:SOVABA>2.0.CO;2.

Rose, W. I., S. Bonis, R. E. Stoiber, M. Keller, and T. Bickford (1973), Studies of volcanic ash from two recent Central American eruptions, Bull. Volcanol., 37(3), 338-364, doi:10.1007/BF02597633.

Rose, W. I., A. T. Anderson, L. G. Woodruff, and S. A. Bonis (1978), The October 1974 basaltic tephra from Fuego volcano: Description and history of the magma body, J. Volcanol. Geotherm. Res., 4, 3-53, doi:10.1016/ 0377-0273(78)90027-6.

Rose, W. I., R. L. Chuan, R. D. Cadle, and D. C. Woods (1980), Small particles in volcanic eruption clouds, Am. J. Sci., 280, 671-696, doi:10.2475/ ajs.280.8.671.

Rosi, M., A. Bertagnini, and P. Landi (2000), Onset of the persistent activity at Stromboli volcano (Italy), Bull. Volcanol., 62, 294-300.

Smith, D. B., R. A. Zielinski, and W. I. Rose (1982), Leachability of uranium and other elements from freshly erupted volcanic ash, J. Volcanol. Geotherm. Res., 13, 1-30, doi:10.1016/0377-0273(82)90017-8.

Smith, D. B., R. A. Zielinski, H. E. Taylor, and M. B. Sawyer (1983), Leaching characteristics of ash from May 18, 1980, eruption of Mount St. Helens volcano, Washington, Bull. Volcanol., 46(2), 103-124, doi:10.1007/BF02597580.

Stevenson, D. S., C. E. Johnson, W. J. Collins, and F. G. Derwent (2003), The tropospheric sulphur cycle and the role of volcanic $\mathrm{SO}_{2}$, Geol. Soc. Spec. Publ., 213, 295-305.

Stewart, C., D. M. Johnston, G. S. Leonard, C. J. Horwell, T. Thordarson, and S. J. Cronin (2006), Contamination of water supplies by volcanic ashfall: A literature review and simple impact modelling, J. Volcanol. Geotherm. Res., 158, 296-306, doi:10.1016/j.jvolgeores.2006.07.002.

Stoiber, R. E., and W. I. Rose Jr. (1974), Fumarole incrustations at active Central American volcanoes, Geochim. Cosmochim. Acta, 38, 495-516, doi:10.1016/0016-7037(74)90037-4.

Stoiber, R. E., and S. N. Williams (1990), Monitoring active volcanoes and mitigating volcanic hazards: The case for including simple approaches, J. Volcanol. Geotherm. Res., 108, 303-341.

Symonds, R. B., W. I. Rose, G. J. S. Bluth, and T. M. Gerlach (1994), Volcanic-gas studies: Methods, results and applications, in Volatiles in Magmas: Reviews in Mineralogy, edited by M. R. Carroll and J. R. Halloway, chap. 1, pp. 1-66, Mineral. Soc. of Am., Washington, D. C.

Taylor, P. S., and R. E. Stoiber (1973), Soluble material on ash from active Central American volcanoes, Geol. Soc. Am. Bull., 84(3), 1031-1042, doi:10.1130/0016-7606(1973)84<1031:SMOAFA>2.0.CO;2.

Textor, C., H. F. Graf, and M. Herzog (2003), Injection of gases into the stratosphere by explosive volcanic eruptions, J. Geophys. Res., 108(D19), 4606, doi:10.1029/2002JD002987.

Thomas, E., and P. R. Buseck (1983), Characterisation of a rural aerosol from Eastern Arizona, Atmos. Environ., 17, 2299-2301, doi:10.1016/ 0004-6981(83)90228-7.

Varekamp, J. C., and J. F. Luhur (1996), Volatile element budgets of explosive eruptions: Contributions from volatiles adsorbed on fine ashes, paper presented at Chapman Conference on Crater Lakes: Terrestrial Degassing and Hyper-Acid Fluids in the Environment, AGU, Washington, D. C.

Varekamp, J. C., J. F. Luhr, and K. L. Prestegaard (1984), The 1982 eruptions of El Chichon Volcano (Chiapas, Mexico): Character of the eruptions, ash-fall deposits, and gas phase, J. Volcanol. Geotherm. Res., 23, 39-68, doi:10.1016/0377-0273(84)90056-8.

Varekamp, J. C., E. Thomas, M. Germani, and P. R. Buseck (1986), Particle geochemistry of volcanic plumes of Etna and Mount St. Helens, J. Geophys. Res., 91, 12,233-12,248, doi:10.1029/JB091iB12p12233.

Whitham, C. S., C. Oppenheimer, and C. J. Horwell (2005), Volcanic ash-leachates: A review and recommendations for sampling methods, J. Volcanol. Geotherm. Res., 141, 299-326, doi:10.1016/j.jvolgeores. 2004.11.010.

Woods, D. C., R. L. Chuan, and W. I. Rose (1985), Halite particles injected into the stratosphere by the 1982 El Chichon eruption, Science, 230, 170-172, doi:10.1126/science.230.4722.170.

Zoller, W. H., J. R. Parrington, and J. M. Phelan-Kotra (1983), Iridium enrichment in airborne particles from Kilauea volcano: January 1983, Science, 222, 1118-1121, doi:10.1126/science.222.4628.1118.

A. Aiuppa and E. Bagnato, Dipartimento CFTA, Università degli Studi di Palermo, Via Archirafi 36, I-90123 Palermo, Italy. (emanuelabagnato@ virgilio.it)

D. Andronico, A. Cristaldi, and L. Miraglia, Istituto Nazionale di Geofisica e Vulcanologia, Sezione di Catania, Piazza Roma 2 Catania, I-95123 Catania, Italy.

L. Brusca and M. Liotta, Istituto Nazionale di Geofisica e Vulcanologia, Sezione di Palermo, via Ugo La Malfa, 153, I-90146 Palermo, Italy. 